\title{
Data Mining Decision Tree Models of Multicultural Acceptability of Multicultural Adolescents in Korea: Focusing on Language Skills (Listening, Speaking, Reading, Writing) of Korean and Mother's Native Languages
}

Eun Ju Lee

Department of Communication Disorders, Ewha Womans University, Seoul, Korea

Correspondence: Eun Ju Lee, $\mathrm{PhD}$ Department of Communication Disorders, Ewha Womans University, 52 Ewhayeodae-gil, Seodamun-gu, Seoul 03760, Korea Tel: $+82-2-3277-2120$

Fax: +82-2-3277-2122

E-mail:imfedra@naver.com

Received: April 5, 2020

Revised: May 8, 2020

Accepted: May 13, 2020

This work was supported by the BK21 PLUS project funded by the Ministry of Education, Korea (2020).
Objectives: There have been no studies of the association between multicultural acceptance and Korean language proficiency in the studies of cross-cultural and multicultural families. Therefore, the purpose of this study was to examine the effects of both Korean and foreign languages (multicultural mother's native language) skills as factors that influence multicultural acceptance among multicultural adolescents. Methods: A decision tree analysis was conducted to examine the relationship between language skills (Korean and foreign languages) predicting multicultural acceptance among 1,439 (2012 yr. 11 years old) and 1,238 (2015 yr. 14 years old) multicultural adolescents in MAPS (Multi-cultural Adolescents Panel Survey) by the NYPI (National Youth Policy Institute). Results: For multicultural adolescents who are 11 years old and in the fifth grade of elementary school, the ability of multicultural adolescents to speak Korean and the ability of mothers to write in Korean predict multicultural acceptability. And for multicultural adolescents who are 14 years old and in the second grade of middle school, the ability of foreign mothers to listen to Korean language and the ability of multicultural teenagers to listen to Korean language acted as variables to predict the multicultural acceptance. Conclusion: It is not by foreign language proficiency that we embrace multiculturalism, but by the Korean language ability of multicultural adolescents and the Korean language proficiency of minority multicultural subjects (mother of multicultural families) that are the main influences in this study. However, these findings may be unique to Korea's multicultural society, where marriage immigrants account for a majority, so there is caution in interpreting the results.

Keywords: MAPS, Multicultural acceptance, Language skills, Decision tree analysis, Korean marriage immigrant family
교차문화 의사소통능력(Cross-cultural Communication

Competence)

다문화 사회 구성원 간의 이해와 소통을 위해서는 다른 문화 배 경을 가진 사람과의 상호작용을 통해 상대방의 언어를 이해하고, 문화 간 의사소통 속에서 다른 문화 배경을 가진 사람들의 사회적 인식, 생각 패턴 및 행동을 이해하고 교류하여 문화간 의사소통 문
제를 줄여가는 것이 요구된다. 즉 물리적 통합 이외에 다문화 사회 공동체는 서로가 같은 공간에서 생활하는 동일한 사회 구성원이라 는 상호 문화적 이해와 공감, 교차문화 인지와 소통기술 능력이 요 구된다. 국외에서는 이러한 능력을 문화 간 의사소통 능력(Intercultural Communication Competence), 교차문화 의사소통 능력 (Cross-cultural Communication Competence), 또는 국제적 의사 
소통(Global Communication) 능력이라고 명명하고 있다(Chen \& Starosta, 2000).

그리고 Chen과 Starosta $(1996,2000)$ 는 교차문화 의사소통 능 력을 문화 간 의사소통 과정에서 상호작용자들 간의 인지적, 감정 적, 행동적(cognitive, affective, and behavioral ability of interactants) 의사소통 능력으로 구성된 복합적인 개념이라 정의하였다. 즉, 교차문화 의사소통 능력의 인지적 측면은 '우리가 생각하고 행 동하는 방식에 영향을 미치는 문화 관습에 대한 이해’를 가리키는 문화간 인식(Intercultural Awareness) 개념이라 보았다. 그리고 교 차문화 의사소통 능력의 감정적인 측면은 상호작용 상대자들이 '문화 간의 차이를 이해하고, 인정하고, 받아들이도록 동기를 부여 하려는 적극적인 이해의 욕구 또는 감정'을 의미하며 문화 간 감수 성(Intercultural Sensitivity) 개념으로 정의하였다. 그리고 교차문 화 의사소통 능력의 행동적 측면은 '교차문화 상호작용에 있어 의 사소통의 목표를 확인하여 일을 잘 완수할 수 있는 능력'을 지칭하 는 것으로 문화 간 기술력(Intercultural Adroitness)으로 표현하였 다. 즉 교차문화 의사소통 능력은 문화 차이를 이해하고 감정적인 편견이나 고정관념을 배제하고, 문화가 다른 상황에서도 적절하게 행동하는 내용이라 정의하였다(Figure 1).

오랜 다문화 사회 경험을 가진 북미와 유럽국가들은 다문화 사회 문제를 겪으면서 다양한 교차문화 의사소통 문제에 대한 연구들이 이루어졌다. 특히, 여러 민족 사람들에 의해 새롭게 구성된 나라인 미국에서는 교차문화에 대한 연구가 이루어지기 훨씬 전인 1925년 대부터 1990년 후반까지 Bogardus $(1947,1971)$ 에 의해 개발된 '사회 적 거리 척도(Bogardus social distance scale)'를 이용하여 인종 및 민족 집단과 같은 다양한 사회 집단 구성원들 간의 친밀도와 사회

\section{Intercultural Communication Competence (ICC) (Cross-cultural communication competence) (Global communication)}

\section{Intercultural awareness (The cognitive aspect of intercultural communication)}

Intercultural sensitivity (The affective aspect of intercultural communication)

Intercultural adroitness (The behavioral aspect of intercultural communication)

Figure 1. The components of ICC.
접촉 의도를 심리적으로 측정하는 교차문화감수성과 관련된 연구 가 많이 진행되었다(Akerlof, 1997; Bogardus, 1971; Giles \& Evans, 1990; Hraba, Radloff, \& Gray-Ray, 1999; Law \& Lane, 1987; Lee, Sapp, \& Ray, 1996; Salzinger, Hammer, Portoy, Polgar, \& Polgar, 1970; Scandrette, 1958; Triandis \& Triandis, 1962). 이는 다양한 민 족으로 구성된 미국 사회 구성원 간의 상호관계 인식의 문제가 1990년 이전부터 얼마나 컸는지를 짐작할 수 있게 하는 결과이다.

그리고 1990년 후반부터 2010년까지는 교차문화(Cross-culture, or Intercultural)에 대한 용어가 사용되기 시작하였으며, 사회적 거 리 척도에서 사용되고 있는 '교차문화 감수성' 측면 이외의 교차문 화적 인지와 행동 측면이 추가된 다양한 교차문화 의사소통 능력 평가도구가 심리학과 경영학, 의사소통학, 그리고 교육학 연구자들 에 의해 개발되었다. 이는 1990년 후반부터는 수동적인 다문화 사 회 구성원에서 적극적인 다문화 사회 구성원으로서 교차문화 능력 을 소양하는 것이 다문화 사회에 적응하기 위해서는 필요한 요인이 되었기 때문인 것으로 해석된다. 그리고 교차문화 의사소통 능력 평가도구의 타당화 연구는 주로 다양한 국가에서 온 대학 내 국제 대학생과 대학원생을 대상으로 타당화 연구가 진행되었다(Brown, 2004; Chen, \& Starosta, 2000; Davis \& Finney, 2006; Loo \& Shiomi, 1999; Montagliani \& Giacalone, 1998; Munroe \& Pearson, 2006; Patterson, 2006; Uttley, 2008; West, 2009).

이후 2010년 이후부터는 타당화 연구가 완료된 여러 교차문화 의사소통 능력 평가도구를 이용하여 다양한 연구가 진행되었다. 이 러한 연구들을 연구 주제에 따라 구분하여 보면 첫째, 교차문화 의 사소통 능력과 다른 문화 집단과의 교류 정도를 살펴본 연구와 둘 째, 외국어 능력과 교차문화 의사소통 능력과의 관련성 연구, 그리 고 셋째, 다양한 응용학문에 교차문화 의사소통 능력을 활용한 연 구 등으로 나누어 볼수 있다.

이에 대해 자세히 살펴보면 첫째, 교차문화 의사소통 능력과 다 른 문화 집단과의 교류 정도를 살펴본 연구에 있어서, 미국 대학 내 수업에서 다문화 사회의 다양한 민족성을 보이는 대학생들에게 세 계문화와 지리에 대한 또래상호작용을 활용한 수업을 제공하였을 때 대상자들의 문화 간 감수성(Intercultural sensitivity)이 향상된 것을 확인하였다(Risner, 2011). 그리고 Benson (2016)은 뉴질랜드 대학에 유학 온 아시아인 대학생들은 다양한 문화 배경을 가진 친 구들을 사귀기 위해 문화 간 감수성을 높여야 하는 데 이는 해외라 는 물리적 공간 이동만으로 저절로 되는 것은 아님을 강조하였다. 즉, 새로운 문화의 친구들을 사귀기 위해 노력해야 하며 우정을 이 어가는 교차문화 능력 함양과 같은 노력이 요구된다고 논의하였다. 그리고 둘째, 외국어 능력이 교차문화 의사소통 능력과 어떠한 
관련이 있는지를 살펴본 연구에 있어서는 한국 청소년 집단을 대 상으로 외국어인 영어 읽기와 쓰기 수업을 진행한 후, 대상자들의 교차문화 감수성을 평가하였다. 그 결과 문화 간 감수성 영역 대부 분은 영어 수업 후 향상된 것을 확인할 수 있었다(Bae, 2012). 그리 고 $\mathrm{Mao}$ (2015)는 중국계 캐나다 이민가정이 정보를 찾는 방법이 중 국 방송을 통해 많이 이루어지고 있음을 확인하였으며, 문화 간 감 수성은 영어 채널을 통해 정보를 더 많이 얻는 집단이 그렇지 않은 집단보다 더 높은 것을 확인하였다. 그러므로 캐나다 내 중국인 이 민자들의 영어 활용 능력을 향상시키는 것이 캐나다 문화에 적응 할 수 있도록 돕게 된다는 것을 강조하였다. 또한 Sarwari와 Abdul Wahab (2017)은 말레이시아 대학에서 17 개국 국제 대학원생들의 문화 간 감수성과 교차문화 의사소통 능력의 관련성을 살펴본 결 과 이러한 두 가지 능력은 다른 문화의 학생들과 의사소통 하는데 있어 중요하게 작용하는 주요 변수로 작용하고 있음을 확인하였다. 그리고 셋째, 다양한 응용학문에 교차문화 의사소통 능력이 적용 되었다. 즉, 법 집행권자, 국제 비즈니스 전문가, 의료 전문가를 대상 으로 교차문화 의사소통 능력 향상 프로그램 적용 효과를 측정하 는데 활용하였다(Kelly \& Meyers, 1995).

\section{다문화 수용성(Multicultural acceptance)}

국내에서는 교차문화 의사소통 능력 전반을 측정하는 평가도구 에 대한 연구가 진행되지는 못하였고, 현재까지는 '다문화 수용성 (Multicultural Acceptance)' 연구가 다수 진행되어 왔다. 여기에서 의 다문화 수용성은 국외 교차문화 의사소통 능력 기준에 의하여 분류하면, '문화 간의 차이를 이해하고, 인정하고, 받아들이도록 동 기를 부여하려는 적극적인 이해의 욕구 또는 감정'을 의미하는 문 화 간 감수성(Intercultural sensitivity: Hammer, Bennett, \& Wise$\operatorname{man}, 2003)$ 측면을 평가하는 것으로 분류할 수 있다(Min, Ahn, $\mathrm{Kim}, \mathrm{Cho}, \& \mathrm{Lee}, 2012)$. 그리고 이외에도 다문화 수용성을 지칭하 는 용어로는 사회적 거리감(Social distance: Laumann, 1965; Westie, 1959), 문화간 유능성(Intercultural competence: Bennett, 2004; Chen \& Starosta, 1996), 다문화 효능성(Multicultural efficacy: Cushner \& Brislin, 1996; Van der Zee \& Van Oudenhoven, 2000) 등으 로 다양하게 사용되고 있다(Kim \& Chung, 2010; Seol \& Chung, 2012).

다문화 수용성은 국내에서 다문화 사회의 구성원으로 살아가는 데 필요한 적응능력을 측정하는 것으로, 타당화 연구가 진행된 평 가도구는 3가지이다. Kim과 Chung (2010)의 다문화 수용성 (Multicultural Acceptance Inventory for Korean Children, MAI)은 한 국의 초등학생을 대상으로 한국 다문화 사회 조건에 적합한 다문
화 수용성을 평가하며 다문화 교육의 효과성을 평가하기 위하여 개발되었다. Min 등 $(2010,2012)$ 은 국책과제를 중심으로 다문화수 용성(Korea Multi-Cultural Inventory, KMCI)에 대한 평가도구를 개발하고 타당화 연구를 진행하여, 타당화가 완료된 다문화 수용 성 평가안을 이용하여 한국 주류문화 집단이 소수 다문화 집단을 수용하는 정도를 평가하였다. 그리고 Ahn, Kim, Ma, Moon과 Lee (2015)는 한국 청소년들의 다문화 수용성(Korean Multi-Culturalism Inventory for Adolescent, KMCI-A)을 평가하고, 그 결과를 통 해 청소년을 위한 다문화사회 정책계획 자료를 수집하였다. 이렇듯 국내 다문화수용성은 초등학생을 대상으로 진행된 다문화 교육의 효과성을 평가하거나, 청소년 및 성인을 위한 다문화 사회정책 마련 을 위한 국책과제 수행 평가도구 개발을 통해 확산된 개념이다.

특히, 국책과제를 통해 개발된 KMCI와 KMCI-A는 국외 교차문 화 의사소통 능력과는 차별되는 다양성, 관계성, 보편성과 같은 세 가지 개념을 인지적, 정서적, 행동적 교차문화 의사소통 능력의 상 위 범주로 도입하였다. 여기에서의 다양성(Diversity)은 다른 집단 의 정체성이나 문화유산의 가치 등을 우리 문화와 동등하게 인정 하는 정도로 정의하였다. 그리고 다양성에는 다양한 문화적 배경 의 이주민의 유입을 인정하는 '문화 개방성(Cultural openness)', 국 민됨의 자격기준에 대해 다양성을 인정하는 '국민 정체성(National identity)', 외국인 및 이주민에 대한 고정관념과 차별에 대한 '고정 관념/차별(Stereotype/Discrimination)'의 3가지 구성요소가 포함 되어 있다. 그리고 관계성(Relationship)은 이민자 집단과 가까운 관 계를 맺고자 하는 정도와 관련되는 것으로, 적극적으로 통합의 관 계를 맺고자 하는지에 대한 개념으로, '일방적 동화기대(Assimilation expectation)', '거부.회피정서(Reject/Avoid)', '교류행동의지 (Intend to interact)'의 3가지 구성요소가 포함되었다. 그리고 보편 성(University)은 외국 이주민에 대한 개방성 혹은 문화 가치의 인 정에 있어서 출신 지역이나 인종 배경에 차이를 두지 않고 외부세 계에 대한 다양한 경계를 초월한 상의 도덕 규범에 따라 문화, 인종, 종교, 지역 차이를 관대히 다루며, 모두가 공통된 세계의 구성원임 을 받아들일 수 있는 인지, 정서, 행동 경향성을 가늠할 수 있는 구 성개념으로 보았다. 그리고 보편성은 경제개발 수준이나 문화적 배 경 등에 등급을 두어 평가하는 '이중적 평가(Dual evaluation)'와 인류애와 같은 보편적 가치추구 및 실천의지의 '세계시민행동의지 (World citizens' action)'의 2가지 구성요소를 포함하고 있다(Min et al., 2012) (Table 1).

국내 다문화 수용성에 대한 연구는 '한국형 다문화 수용성 진단 도구 개발 연구(Min et al., 2010)'가 진행된 2010년 이후부터 활발 하게 진행되었다. 즉, 다양한 다문화 수용성 검사도구가 개발되기 
Table 1. The concepts of multicultural acceptance (KMCl and KMCl-A)

\begin{tabular}{|c|c|}
\hline Concepts & Measurement contents \\
\hline \multicolumn{2}{|l|}{ Diversity } \\
\hline Cultural openness & $\begin{array}{l}\text { The recognition of migrants from various } \\
\text { cultural backgrounds }\end{array}$ \\
\hline National identity & $\begin{array}{l}\text { Recognition of diversity in eligibility } \\
\text { criteria for nationality }\end{array}$ \\
\hline Stereotype/Discrimination & $\begin{array}{l}\text { Stereotypes and discrimination against } \\
\text { foreigners and migrants }\end{array}$ \\
\hline \multicolumn{2}{|l|}{ Relationship } \\
\hline Assimilation expectation & $\begin{array}{l}\text { Expectations of Korean culture assimilation and } \\
\text { acculturation by migrants }\end{array}$ \\
\hline Reject/Avoid & Irrational negative sentiment in migrant contact \\
\hline Intend to interact & $\begin{array}{l}\text { The will to have a friendly relationship with } \\
\text { migrants }\end{array}$ \\
\hline \multicolumn{2}{|l|}{ University } \\
\hline Dual evaluation & $\begin{array}{l}\text { Rank economic development level, cultural } \\
\text { background }\end{array}$ \\
\hline World citizens' action & $\begin{array}{l}\text { Universal will to pursue and practice values, } \\
\text { such as humanity }\end{array}$ \\
\hline
\end{tabular}

Source: Min, M. S., Ahn, S., Kim, Y-S., Cho, H. Y., \& Lee, M. J. (2012). A study on the availability of multicultural water for teenagers (research report 2012-51). Seoul: Ministry of gender equality and family.

보다는 기존에 개발된 타당화 검사도구를 연구대상자의 연령에 맞 게 일부만을 수정 보완하여 연구가 진행되었으며, 2010년부터 2020 년까지 10 년 기간 동안 약 98 편의 많은 연구가 진행되었다. 그리고 국내 다문화 수용성 연구는 국외 연구가 해외 소수의 국제대학 학 생들의 교차문화 의사소통 능력을 측정했던 것과는 달리, 다수의 국내 일반인 유치원생, 초등학생, 청소년, 그리고 대학생 및 성인을 대상으로 다문화 수용성 능력을 살펴보는 연구가 주로 진행되었다 (Kang \& Ko, 2019; Kim \& Yun, 2019; Kwak \& Yang, 2017; Kwon \& Lee, 2015; Kwon \& Lee, 2018; Park \& Won, 2010; Sul \& Chung, 2012; Yang, Choi, Moon, Park, \& Park, 2011). 즉, 주류 집단인 일반인들이 소수의 다문화 집단을 수용하는 인식능력과 감수성, 행동 정도를 살펴보는 것이었다. 그리고 이외에 한국인의 다문화 수용성의 결정 요인을 교육수준 정도에 따라 살펴본 연구(Jung \& Park, 2012; Lee \& Kim, 2012)와 일반아동을 대상으로 다문화 수용성 향상 프로그 램의 효과성을 살펴본 연구(Ham \& Kim, 2018; Hong, 2014; Jung, Kim, \& Hong, 2014; Kong \& Chang, 2018; Park, 2013), 중국인 대학 생이 느끼는 한국인의 다문화 수용성 수준(Park, 2016), 초등학교 교과과정에 나타나는 다문화 수용성 분석(Lee, Kang, \& Park, 2018), 그리고 한국군 장병의 다문화 수용성을 살펴본 연구(Jin \& Park, 2018) 등이 진행되었다. 즉, 국내 다문화 수용성 연구는 다양 한 연령대의 다수 내국인 집단을 중심으로 소수 다문화 집단을 수 용하는 문화간감수성을 측정하는 연구가 대부분이었다.
국외에서 교차문화 의시소통 능력과 언어와의 관련성 연구가 진 행되었듯이 국내에서는 다문화 수용성과 언어와의 관련성 연구가 진행되었다. Park과 Won (2010)은 지역대학에 재학 중인 730명 대 학생을 대상으로 다문화수용성과자기효능감, 독서량, 학업성취도, 외국어능숙도, 성별, 외국인친구 유무, 해외방문체류경험, 자원봉 사 등의 변수와의 관계를 경로분석으로 통해 살펴보았다. 그 결과 외국인친구 유무, 독서량, 학업성취도, 자원봉사 그리고 자기효능감 은 다문화 수용성과 직접적으로 관련되어 있었으며, 외국어 능숙도 와 해외방문경험 변인은 다문화 수용성에 간접적인 효과를 미치는 것으로 나타났다. 그리고 Joo와 Park (2019)의 연구에 의하면 대학 생의 영어학습정도와 다문화 수용성을 측정한 결과 영어능력 점수 가 높은 학생일수록 다문화 수용성 능력이 높게 나타났다. 즉, 다문 화수용성은 언어능력에 의해 영향을 받는 것으로 나타났다.

국내에서는 국외와는 달리 다문화 수용성 연구는 주로 대다수 일반인들을 대상으로 소수의 다문화사회에 대한 수용도를 평가하 고 미래 다문화 사회에 대한 정부정책 마련을 위한 자료 수집의 목 적을 가지고 연구가 진행되었다. 그리고 소수 다문화 집단이 다문 화 사회를 수용하는 정도를 살펴본 연구는 거의 찾아볼 수 없었다. 또한 다문화 수용성과 언어와의 관련성 연구 대부분은 일반인을 대상으로 외국어 능력이 다문화 수용성과 관련되어 있다는 연구 만이 진행되었을 뿐, 다문화 집단을 대상으로 다문화 수용성과 한 국어, 다문화 가정 어머니의 모국어와 관련된 외국어 능력, 또는 어 머니의 한국어 능력과의 관련성에 대한 국내 연구는 찾아볼 수 없 었다. 이에 다문화 수용성과 언어능력과의 관련성을 한국어와 외 국어에 다양하게 노출되어 있는 다문화 청소년들을 대상으로 다문 화 수용성에 영향을 미치는 요인으로서 한국어와 외국어(다문화 청소년 어머니의 모국어) 언어능력 모두의 영향을 살펴보았다. 그 리고 추가적으로 어머니의 한국어능력이 다문화 청소년의 다문화 수용성 예측모델에 영향을 미치는 측면도 살펴보았다. 이에 대한 구체적인 연구문제는 다음과 같다.

\section{연구문제}

연구문제 1. 평균 11 세 초등학교 5 학년 다문화 청소년의 한국어 와 외국어(다문화 청소년 어머니의 모국어) 능력과 다문화 청소년 어머니의 한국어 능력 변수는 다문화 청소년의 다문화 수용성 예 측모형에 있어 어떠한 작용을 하는가?

연구문제 2. 평균 14 세 중학교 2학년 다문화 청소년의 한국어와 외국어(다문화 청소년 어머니의 모국어) 능력과 다문화 청소년 어 머니의 한국어 능력 변수는 다문화 청소년의 다문화 수용성 예측 모형에 있어 어떠한작용을 하는가? 


\section{연구방법}

\section{연구대상}

한국청소년정책연구원(NYPI, National Youth Policy Institute, 2011) 다문화청소년패널조사(MAPS, Multicultural Adolescents Panel Study)는 2011년 4월 기준 각 지방 교육청의 초등학교 4학년 다문화 청소년이 재학 중인 학교 리스트를 통해 전국 2,537 개 초등 학교 4학년에 재학중인 다문화 가정 학생 4,452명(2011년 기준, 교 육청)을 대상으로 층화표집을 실시하여 1,600 명(추출률, $35.9 \%$ )을 1 차 패널로 구축하였다. 현재는 매년 패널을 추적하여 시간의 경과 에 따른 다문화 청소년들의 발달과정과 관련된 변인(개병변인, 언 어능력, 이중문화경험, 지원정책에 대한 태도, 신체적·심리적 특성, 교육/진학/진로 지도 특성, 양육특성)에 대해 시계열적 관점에서 데 이터를 수집하고 있다. 그리고 추적연구인 만큼 관련 변인 중 언어 연령에 적합하지 않은 변수는 일부 제외하거나 수정하여 검사를 진행하고 있으며, 대상자들이 만 24세가 되는 2025년에 16차에 걸 쳐 매년 진행된 추적조사가 마무리될 예정이다.

이번 연구는, 본 연구의 제 1 연구자가 MAPS에서 다문화 청소년 의 언어능력을 한국어와 외국어(다문화 청소년 어머니의 모국어) 로 구분하여 모두 평가한 2차(2012년, 초등학교 5학년)와 5차(2015 년, 중학교 2학년) 패널 데이터를 제공받아 이를 활용하여 분석하 였다. 분석자료인 2차년도 패널은 2012년 6-8월에 조사를 실시하였 으며, 5차년도는 2015년 5-8월에 패널데이터를 수집하였다.

본 MAPS의 모집단 대상자는 국제결혼가정자녀가 대다수이기 는 하지만 중도입국 청소년, 외국인자녀 등도 모두 포함하였다. 이 에 이번 연구에서는 패널 자료를 이용한 연구결과의 타당도를 높이 기 위하여, 2 차년도 1,635 명(100\%) 패널 데이터 중 표본이탈, 중도입 국 청소년과 외국인자녀 196명(11.98\%)을 제외한, 아버지는 한국인 이며 어머니는 외국인인 국제결혼가정 청소년 1,439명만을 대상으 로 하였다. 그리고 5 차년도에는 표본이탈(sample attrition) 인원을 제외한 1,238 명을 대상으로 하였다.

2 차년도 초등학교 5 학년 재학생 1,439 명 중 남학생은 709 명 (49.27\%)이었으며 여학생은 730 명(50.73\%)이었다. 그리고 연령범위 는 10-13세였으며 평균연령은 $10.97(\mathrm{SD}=0.35)$ 이었다. 다문화 청소 년 어머니의 결혼 전 국적은 총 7개(1) 중국: 한족, (2) 중국: 조선족, (3) 베트남, (4) 필리핀, (5) 일본, (6) 태국, (7) 기타)로 구분하였으며 이중 일본(501명, $34.82 \%)$ 이 가장 많았고 다음으로는 필리핀(374 명, $25.99 \%)$, 조선족 중국인(287명, $19.94 \%)$, 한족 중국인(110명, $7.64 \%)$ 순이었다. 그리고 나머지는 기타(77명, 5.35\%), 태국(54명, $3.75 \%)$, 베트남(36명, $2.50 \%)$ 순이었다.
5 차년도 중학교 2학년 재학생 1,238 명 중 남학생은 604 명 (48.79\%)이었으며 여학생은 634명(51.21\%)이었다. 그리고 연령범위 는 13-16세였으며 평균연령은 $13.97(\mathrm{SD}=0.35)$ 이었다. 다문화 청소 년 어머니의 결혼 전 국적은 총 7개(1) 중국: 한족, (2) 중국: 조선족, (3) 베트남, (4) 필리핀, (5) 일본, (6) 태국, (7) 기타)로 구분하였으며 이중 일본(451명, 36.43\%)이 가장 많았고 다음으로는 필리핀(317명, $25.61 \%)$, 조선족 중국인(233명, $18.82 \%)$, 한족 중국인(88명, 7.11\%) 순이었다. 그리고 나머지는 기타(66명, 5.33\%), 태국(49명, 3.96\%), 베트남(34명, 2.75\%) 순이었다(Table 2).

거주지역은 5 개 도별 영역으로(1) 서울특별시, (2) 경인: 경기도+ 인천, (3) 충청 및 강원권, (4) 경상권, (5) 전라 및 제주도) 구분하여 조사하였다. 2 차년도 초등학교 5 학년 다문화 청소년 1,439 명의 거 주지역은 경기.인천이 383 명(26.62\%), 경상도 340명(23.63\%), 전라 도와 제주도 297명(20.64\%), 충청도와 강원도 276명(19.18\%), 서울 이 143 명 $(9.94 \%)$ 이었다. 즉, 다문화 청소년의 거주지역별 비율은 2019년 교육기본통계표의 전국초등학생 지역별 비율(The Korean Ministry of Education, 2019)과 비교하였을 때 전라와 제주도, 충 청도와 강원도 비율이 높게 나타났다. 즉, 전체 초등학생 비율이 경 인, 경상도, 서울, 충청도와 강원도, 전라와 제주도 순이었던 것과는 달리, 다문화 청소년의 거주지역은 경인, 경상도, 전라와 제주도, 충 청도와 강원도, 서울지역 순으로 거주자가 많은 것으로 나타나 지 방거주자가 많은 것으로 나타났다. 이러한 경향은 5 차년도 중학교

Table 2. Participants' information

\begin{tabular}{lcc}
\hline Characteristic & $\begin{array}{c}2012 \\
\text { (2nd MAPS study) }\end{array}$ & $\begin{array}{c}2015 \\
\text { (5th MAPS study) }\end{array}$ \\
\hline Grade & $\begin{array}{c}\text { 5th grade in } \\
\text { elementary school }\end{array}$ & $\begin{array}{c}\text { 2nd grade in } \\
\text { middle school }\end{array}$ \\
Gender (\%) & $709(49.27)$ & $604(48.79)$ \\
Male & $730(50.73)$ & $634(51.21)$ \\
Female & $1,439(100)$ & $1,238(100)$ \\
All & & \\
Age (yr) & $10-13$ & $13-16$ \\
Range & $10.97(0.35)$ & $13.97(0.35)$ \\
Average (SD) & & $88(7.11)$ \\
Mother's Nationality & $110(7.64)$ & $233(18.82)$ \\
China (Han, Others) & $287(19.94)$ & $34(2.75)$ \\
China (Ethnic Koreans) & $36(2.50)$ & $317(25.61)$ \\
Vietnam & $374(25.99)$ & $451(36.43)$ \\
Philippines & $501(34.82)$ & $49(3.96)$ \\
Japan & $54(3.75)$ & $66(5.33)$ \\
Thailand & $77(5.35)$ & \\
The others &
\end{tabular}

Values are presented as number (percentage). 
Table 3. Number of children (\%) by residential area (5 different regions)

\begin{tabular}{lccc}
\hline \multirow{2}{*}{ Region } & \multicolumn{3}{c}{ Statistical date } \\
\cline { 2 - 4 } & 2019 (The Ministry of Education) & 2012 (2nd MAPS study) & 2015 (5th MAPS study) \\
\hline Seoul & $422,293(15.37)$ & $143(9.94)$ & $116(9.37)$ \\
Gyeongi (Gyeonggi+ Incheon) & $930,597(33.87)$ & $383(26.62)$ & $309(24.96)$ \\
Chungcheong and Gangwon & $395,385(14.39)$ & $276(19.18)$ & $250(20.19)$ \\
Gyeongsang-do & $607,691(22.12)$ & $340(23.63)$ & $294(23.75)$ \\
Jeola and Jeju-do & $391,253(14.24)$ & $297(20.64)$ & $269(21.73)$ \\
All & $2,747,219(100)$ & $1,439(100)$ & $1,238(100)$ \\
\hline
\end{tabular}

Table 4. Items and scale of multicultural acceptance measure

\begin{tabular}{|c|c|c|c|c|c|}
\hline \multirow{2}{*}{ No } & \multirow{2}{*}{ Items } & \multicolumn{4}{|c|}{ Scale } \\
\hline & & Strongly disagree & Disagree & Agree & Strongly agree \\
\hline 1 & I can accept someone with a different cultural background as my neighbor. & 1 & 2 & 3 & 4 \\
\hline 2 & I can accept teenagers with different cultural backgrounds as classmates. & 1 & 2 & 3 & 4 \\
\hline 3 & I can be best friends with other teenagers with different cultural backgrounds. & 1 & 2 & 3 & 4 \\
\hline 4 & I can have a person with a different cultural background as a boyfriend/girlfriend & 1 & 2 & 3 & 4 \\
\hline 5 & When I grow up, I can marry someone with a different cultural background. & 1 & 2 & 3 & 4 \\
\hline
\end{tabular}

Source: The Korea Youth Policy Institute (2011). Multicultural Youth Panel Survey: 1st to 6th year youth survey table. Seoul: Author.

2 학년 다문화 청소년 1,238 명에서도 유사하였다. 자세한 대상자 거 주지역 정보는 Table 3 에 제시하였다.

\section{측정도구}

다문화 수용성(Multicultural acceptance)

MAPS 연구에서 사용된 '다문화 수용성' 문항은 Yang과 Jung (2008)의 다문화 수용도 문항 일부를 한국청소년정책연구진이 참 고하여 수정·보완하여 사용하였으며 총 5 개 문항으로 구성되어 있 다. 이에 대해 자세히 살펴보면, 첫 번째 문항은, '나와 문화적 배경 이 다른 사람을 이웃으로 받아들일 수 있다', 두 번째 문항은, '나와 문화적 배경이 다른 청소년을 같은 반 친구로 받아들일 수 있다', 세 번째 문항은, ‘나와 문화적 배경이 다른 청소년과 가장 친한 단짝이 될 수 있다', 네 번째 문항은 '이성 친구를 사귀게 된다면, 나와 문화 적 배경이 다른 사람을 이성 친구로 사귈 수 있다', 그리고 다섯 번 째 문항은, '커서 나와 문화적 배경이 다른 사람과 결혼할 수 있다' 로 구성되어 있다. 즉 MAPS의 다문화 수용성 문항 내용은 다양성, 관계성, 보편성과 같은 다양한 다문화 수용성의 구성요소를 포함 하기 보다는 다문화 배경의 사람에 대해 사회적 거리를 어느 정도 둘 것인지를 '이웃 - 친구 - 단짝 친구 - 이성 친구 - 결혼 상대자'의 개념을 적용하여 간단하게 평가하도록 하였다. 그러므로 이번 연구 에 사용된 다문화 수용성(Yang \& Jung, 2008)은 다른 문화에 대한 교차문화 감수성의 일부인 사회적 거리감과 유사한 개념으로 이해
할수 있다.

문항에 대한 점수화는 전혀 그렇지 않다(1점)와 매우 그렇다(4 점)와 같은 4점 리커트 척도[4-point Likert-type scale; Strongly disagree (1) - Disagree (2) - Agree (3) - Strongly agree (4)]를 사용 하였다. 본 척도의 Cronbach's alpha는 .86이며, 5 문항의 총점이 높 을수록 다문화수용성이 높은 것을 의미한다(Table 4).

\section{다문화 청소년의 한국어 능력}

MAPS는 다문화 청소년 스스로가 자신의 한국어 능력에 대하 여 생각하여 4 가지 영역(듣기, 말하기, 읽기, 쓰기) 별로 구분하여 평 가하도록 하였다. 즉, 자신이 생각하는 한국어 능력을 전혀 못한다 (1점)와 매우 잘한다(4점)와 같은 4점 리커트 척도[4-point Likerttype scale; Not at all (1) - Not good (2) - Pretty good (3) - Very good (4)]를 사용하여 스스로를 평가하도록 하였다.

\section{다문화 청소년의 외국어(다문화 청소년 어머니의 모국어) 언어능력}

MAPS는 다문화 청소년 스스로가 자신의 외국어(다문화 청소 년 어머니의 모국어)능력을 4 가지 영역(듣기, 말하기, 읽기, 쓰기) 별 로 구분하여 평가하도록 하였다. 즉, 자신의 외국어 능력을 전혀 못 한다(1점)와 매우 잘한다(4점)와 같은 4점 리커트 척도[4-point Likert-type scale; Not at all (1) - Not good (2) - Pretty good (3) - 
Very good (4)]를 사용하여 스스로를 평가하도록 하였다.

\section{다문화 청소년 어머니의 한국어 능력}

MAPS는 다문화 청소년이 다문화 청소년 어머니의 한국어 능력 을 4가지 영역(듣기, 말하기, 읽기, 쓰기)에 대하여 전혀 못한다(1점) 와 매우 잘한다(4점)와 같은 4점 리커트 척도[4-point Likert-type scale; Not at all (1) - Not good (2) - Pretty good (3) - Very good (4)] 를 사용하여 평가하도록 하였다.

\section{연구절차}

이번 연구는 다문화 청소년의 한국어와 외국어(다문화 청소년 어머니의 모국어) 능력, 다문화 청소년 어머니의 한국어 능력 변수 가 다문화 청소년의 다문화 수용성 예측에 어떻게 작용하는 지를 연령변화와 함께 살펴보기 위해 MAPS 데이터를 이용하였다.

데이터 이용 절차는 다음과 같다. 우선, 연구자는 한국청소년정 책연구원(NYPI) 홈페이지에서 공공데이터로 활용되고 있는 MAPS 1차(2011년)-7차(2017년) 데이터를 요청하였다. 다음에 이 메일로 제공받은 데이터에 대해 MAPS 조사 내용을 면밀히 분석하 여 보았다. 그 결과 다문화 청소년의 한국어와 외국어(다문화 청소 년 어머니의 모국어)를 모두 조사한 것은 2차(2012년, 초등학교 5 학년) 데이터부터 5 차(2015년, 중학교 2학년) 데이터까지였다. 이에 본 연구자는 종단 변화의 간격을 3 년으로 설정하고 2 차와 5 차 데이 터를 이용하여 의사결정나무모형 분석을 실시하여 예측 변인의 종 단변화를 비교하였다.

MAPS의 조사절차는 전문조사원에 의한 설문지 면접조사 방식 으로 진행하였으며 조사형식은 Computer Assisted Personal Interviewing (CAPI)이었다. 어머니의 경우는 한국어 및 총 9 개 외국어 (외국어와 한국어를 함께 제시)로 번역된 설문지가 제공되었으며, 제공된 설문지 중 어머니가 언어를 선택할 수 있었다. 2 차년도 패널 은 2012년 6-8월에 조사를 실시하였으며, 5차년도는 2015년 5-8월 에 패널데이터를 수집하였다.

\section{자료분석}

분석기법

수집된 자료는 IBM SPSS 25.0 프로그램을 사용하여 데이터 마 이닝 기법 중 하나인 의사결정나무모형 분석(Decision Tree Analysis)을 활용하였다. 그리고 본 연구에서는 의사결정나무모형 구축 을 위한 알고리즘으로 Chi-squared Automatic Interaction Detector (CHAID; Kass, 1980)를 활용하였다.

\section{의사결정나무모형 알고리즘}

의사결정나무모형은 목적변수의 척도와 분리기준으로 사용되 는 알고리즘에 따라 분류할 수 있다. 의사결정나무모형 중 가장 보 편적으로 사용되는 것은 CHAID이다. CHAID는 일반적으로 목 적변수와 질적변수 모두가 질적변수인 경우에 $\chi^{2}$ 검정을 이용하여 분리와 병합을 반복하면서 통계적으로 유의한 차이가 있는 마디를 분류해내는 방법이다.

본 연구에 활용된 CHAID는 기본적으로 다음과 같은 두 가지의 단계를 거쳐서 분리가 일어난다. 첫 번째 단계는 모든 예측변수들 에 대해서 최적분리를 탐색하는 과정으로서, $\chi^{2}$ 통계량 값과 이에 상응하는 $p$ 값을 산출한다. 이 단계에서는 예측변수의 범주 중에 유 의한 차이가 없는 것들을 찾아서 병합도 이루어진다. 두 번째 단계 는 첫 번째 단계에서 계산된 $p$ 값을 비교하여 가장 작은 $p$ 값을 갖는 예측변수를 선택하고 이를 기준으로 자식마디를 형성한다. 이러한 과정을 반복하여 의사결정나무모형이 형성된다(Lee, 2019).

\section{의사결정나무모형 분석}

의사결정나무모형 분석에 있어 국내 다문화 청소년들의 다문화 수용성은 목표변수(Target variable)로, 다문화 청소년의 한국어(듣 기, 말하기, 읽기, 쓰기)와 외국어 능력(다문화 청소년 어머니의 모 국어: 듣기, 말하기, 읽기, 쓰기), 그리고 다문화 청소년 어머니의 한 국어 능력(듣기, 말하기, 읽기, 쓰기)의 12 가지 언어능력 변수를 예 측변수(predictor variable)로 하여 분석하였다.

그리고 예측변수 분석에 있어 의사결정나무모형이 데이터에 과 적합(overfitting)되는 것을 방지하기 위해 나무의 성장을 멈추는 중지규칙(stopping rule)으로 가지를 이루는 마디의 개수를 의미하 는 나무 깊이(depth)를 최대 5 로 제한하였으며, 전체 훈련 데이터에 서 비율로써 레코드 수는 부모마디(parent node)의 최소 레코드 수 $2 \%$, 자식마디(child node)의 최소 레코드 수 $1 \%$ 로 설정하였다. 다 양한 범주의 조합을 검증할 때 유의수준은 조정되는 데 유의수준 값을 조정하기 위해 위양성 오류 (false-positive error)의 제어에 효 과적인 Bonferroni 방법을 사용하였으며, 분할과 병합을 위한 유의 수준은.05로 하였다.

\section{연구결과}

\section{측정변수 기술통계}

측정변수인 다문화 청소년의 다문화 수용성, 한국어 능력, 외국 어(어머니의 모국어) 능력과 어머니의 한국어 능력을 초등학교 5 학 년(평균 11 세)과 중학교 2학년(평균 14세) 때로 구별하여 최소값과 
Table 5. Descriptive statics of variables

\begin{tabular}{|c|c|c|c|c|c|c|c|c|}
\hline & \multicolumn{4}{|c|}{ 2nd-year elementary school students (11 years old) } & \multicolumn{4}{|c|}{2 nd grade in middle school (14 years old) } \\
\hline & Min & Max & M & (SD) & Min & Max & M & (SD) \\
\hline \multicolumn{9}{|c|}{ Multicultural acceptance } \\
\hline Neighbor & 1 & 4 & 3.00 & .67 & 1 & 4 & 3.20 & .64 \\
\hline Classmates & 1 & 4 & 3.08 & .65 & 1 & 4 & 3.30 & .59 \\
\hline Best friends & 1 & 4 & 2.99 & .70 & 1 & 4 & 3.22 & .64 \\
\hline Boy (girl) friends & 1 & 4 & 2.79 & .77 & 1 & 4 & 3.03 & .72 \\
\hline Marriage & 1 & 4 & 2.77 & .79 & 1 & 4 & 2.96 & .78 \\
\hline Sum & 5 & 20 & 14.63 & 2.85 & 5 & 20 & 15.71 & 2.80 \\
\hline \multicolumn{9}{|c|}{ Adolescent's Korean } \\
\hline Listening & 2 & 4 & 3.67 & .51 & 1 & 4 & 3.73 & .48 \\
\hline Speaking & 2 & 4 & 3.67 & .51 & 1 & 4 & 3.72 & .49 \\
\hline Reading & 1 & 4 & 3.63 & .55 & 1 & 4 & 3.71 & .51 \\
\hline Writing & 1 & 4 & 3.56 & .60 & 1 & 4 & 3.66 & .55 \\
\hline \multicolumn{9}{|c|}{ Adolescent's foreign language } \\
\hline Listening & 1 & 4 & 2.38 & .99 & 1 & 4 & 2.12 & .94 \\
\hline Speaking & 1 & 4 & 2.35 & .96 & 1 & 4 & 2.07 & .90 \\
\hline Reading & 1 & 4 & 2.17 & 1.00 & 1 & 4 & 1.85 & .90 \\
\hline Writing & 1 & 4 & 2.06 & .99 & 1 & 4 & 1.77 & .87 \\
\hline \multicolumn{9}{|l|}{ Mother's Korean } \\
\hline Listening & 1 & 4 & 2.38 & .99 & 1 & 4 & 3.36 & .58 \\
\hline Speaking & 1 & 4 & 2.35 & .96 & 1 & 4 & 3.38 & .59 \\
\hline Reading & 1 & 4 & 2.17 & 1.00 & 1 & 4 & 3.23 & .65 \\
\hline Writing & 1 & 4 & 2.06 & .99 & 1 & 4 & 3.06 & .71 \\
\hline
\end{tabular}

Multicultural acceptance=4-point Likert-type scale [Strongly disagree (1 points)-Strongly agree (4 points)]; Korean and foreign language ability=4-point Likert-type scale [Not at all (1 points)-Very good (4 points)]; Adolescent's Korean=Ability of multicultural adolescent's Korean; Adolescent's foreign language=Multicultural adolescent's ability of mother's native language; Mother's Korean=Ability of Mother's Korean.

최대값, 그리고 평균과 표준편차를 Table 5에 제시하였다.

다문화수용성 5 개 문항에 대하여 11살(초등학교 5학년) 다문화 청소년들은 2.7 이상(4점이 매우 그러하다)의 다문화 수용 정도를 보이고 있으며, 14 살(중학교 2학년) 다문화 청소년들은 약 3.0 이상 의 다문화 수용성을 보이고 있다. 그리고 다문화 수용성 5 문항 중 패널이 11살 때는 첫 번째(나와 문화적 배경이 다른 사람을 이웃으 로 받아들일 수 있다.')와 두 번째 문항('나와 문화적 배경이 다른 청소년을 같은 반 친구로 받아들일 수 있다.')에 대하여 가장 수용 적인 태도를 보였고, 패널이 14살이 되었을 때는 두 번째('나와 문화 적 배경이 다른 청소년을 같은 반 친구로 받아들일 수 있다.')와 세 번째 문항('나와 문화적 배경이 다른 청소년과 가장 친한 단짝이 될 수 있다')에 대하여 가장 수용적인 태도를 보였다. 즉, 11 살 때(초 등학교 5학년) 평균 이상의 긍정적 다문화 수용성 성향은 3 년 뒤 14 살(중학교 2학년)이 되어서는 약 3.0 이상으로 증진된 것을 알 수 있었다(Table 5).

그리고 다문화 청소년의 한국어 능력은 듣기, 말하기, 읽기와 쓰 기 영역 모두 초등학교 5 학년때나 중학교 2학년 때 모두 3.5 점 이상
(4점이 매우 잘함)으로 측정되어, 평균 이상 잘하는 편으로 평가하 였다. 4 가지 언어 영역(듣기, 말하기, 읽기, 쓰기)으로 구분하여 연령 별 차이를 구분하여 보면 11살과 14살 모두 쓰기에 대한 부분이 다 른 영역에 비하여 점수가 낮은 경향이 보였다. 그리고 연령 별 차이 에 있어 한국어 능력은 차이를 보였다. 11 살 때는 듣기 $(\mathrm{M}=3.67)$ 와 말하기 $(\mathrm{M}=3.67)$ 를 동일한 수준으로 평가하였으나, 14살 때는 듣기 $(\mathrm{M}=3.73)$ 를 말하기 $(\mathrm{M}=3.72)$ 보다 더 잘하는 것으로 평가하였다.

다문화 청소년의 외국어 능력(어머니나라 언어)은 초등학교 5 학 년때 평균 2.4 미만으로 평균보다 낮은 '평균 하' 수준으로 평가하였 으며, 3년 뒤 중학교 2학년 때는 1.77-2.12점 사이의 '잘 못함' 수준 으로 평가하여 이전보다 낮은 수준으로 평가하였다. 즉, 한국어 능 력은 11 살 때 보다 14 살이 되었을 때 상승한 것에 비하여 외국어(다 문화 청소년의 어머니 모국어) 능력은 '평균 하'에서 '잘 못함' 수준 으로 하향된 것으로 나타났다.

그리고 다문화 청소년 어머니의 한국어 능력은 다문화 청소년이 어머니에 대해 평가한 것으로, 11 살(초등학교 5 학년)일 때는 2.5 미 만의 ‘평균 이하'의 수준으로 평가하였지만, 3 년 뒤 다문화 청소년이 
14 살(중학교 2학년)이 되었을 때는 3.0 이상의 '평균 이상'의 수준으 로 평가하였다. 특히 다문화 청소년이 14살(중학교 2학년)일 때, 어 머니의 한국어 능력에 대하여 듣기와 말하기는 약 3.4(매우 잘함(4 점))로 평가하여, ‘잘 함' 이상으로 여기고 있음을 확인하였다.

\section{다문화 청소년의 다문화 수용성 예측모델: 11 살(초등학교 5학년)}

\section{의사결정나무모형 분석}

평균 만 11 세(초등학교 5학년) 국내 다문화 청소년들의 다문화 수용성(Target variable)을 예측하는 언어능력 변수에는 다문화 청 소년의 한국어 능력(듣기, 말하기, 읽기, 쓰기), 외국어 능력(다문화 청소년 어머니의 모국어: 듣기, 말하기, 읽기, 쓰기), 그리고 다문화 청소년 어머니의 한국어 능력(듣기, 말하기, 읽기, 쓰기)과 같은 12 가 지 예측변수(Predictor variable)가 포함되었다. 위의 12 개 예측변수 는 '전혀 못한다(1) 매우 잘한다(4)'로 측정하였다. 그리고 중지규칙 (stopping rule)으로 가지를 이루는 마디의 개수를 의미하는 나무 깊이(depth)를 최대 5 로 제한한 결과 4 마디 깊이 2 에서 정지하였다.
분석결과 Figure 2에서 알 수 있듯이, 11 세(초등학교 5 학년) 다문 화 청소년의 다문화 수용성에 대한 첫 번째 분리는 다문화 청소년 의 한국어(말하기) 능력에 의하여 이루어졌다. 본 연구는 의사결정 나무모형 알고리즘 중 CHAID를 적용한 것으로 첫 번째 분리는 다 문화 청소년이 자신의 한국어 말하기 능력에 대해 '매우 잘한다'고 응답한 집단과 그렇지 않은 나머지 집단으로 구분하여 이루어졌다. 다문화 청소년 중 자신의 한국어 말하기 능력에 대해 매우 잘한다 고 응답한 집단의 다문화 수용성 평균은 14.94 , 나머지 응답 집단 ('잘하는 편이다'와 '못하는 편이다'라고 응답한 대상자)의 다문화 수용성 평균은 13.96이었다(Figure 1). 즉, 한국어 말하기 능력이 '매우 잘한다'에 속하는 다문화 청소년에게서 다문화 수용성에 대 한 첫 번째 분리가 나타났으며 또한 이러한 집단에게서 다문화 수 용성이 더 높게 나타났다.

그리고 다문화 청소년의 다문화 수용성에 대한 두 번째 최적분 리는 다문화청소년 어머니의 한국어 쓰기 능력에 의해 분리되었다. 즉, 한국어 말하기를 매우 잘하는 다문화 청소년 중, 어머니의 한국 어 쓰기 능력이 잘하는 편(잘함, 매우 잘함)에 속하는 다문화 청소

Multicultural acceptance
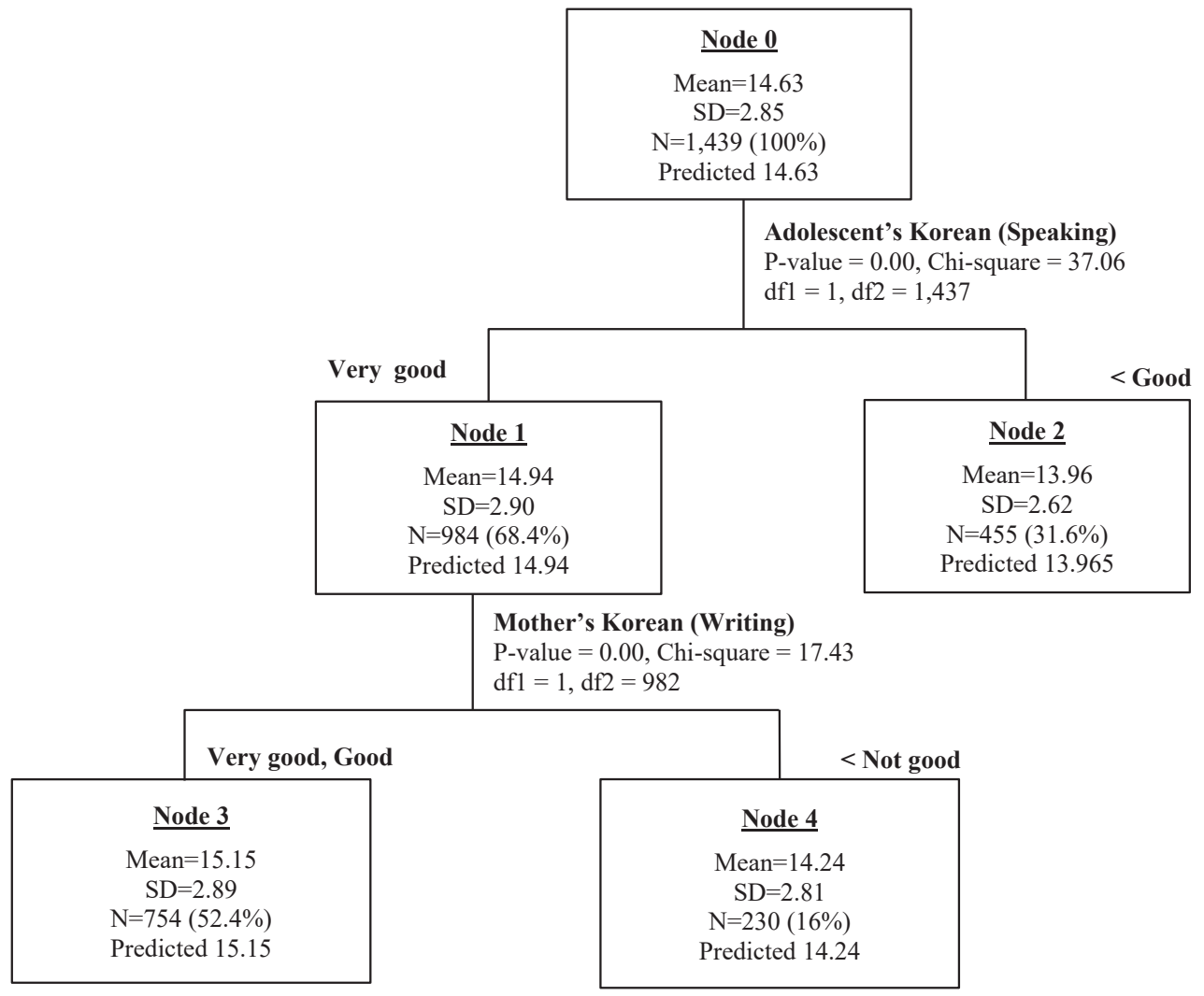

Figure 2. Decision tree predicting multicultural acceptance outcomes at average 11 years old in MAPS based on Korean, foreign language, and mother's Korean language scores. 
Eun Ju Lee • Data Mining Decision Tree Models of Multicultural Acceptability

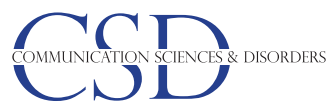

년 집단에게서 다문화수용성이 높게 나타났다(Figure 2).

\section{모형 평가}

다문화 수용성에 대한 의사결정나무에 대한 평가는 위험도표를 통해 진행하였다. 예측위험(risk estimate)은 자식마디에서의 집단 내 분산을 의미하는데, 전체분산에서 각 마디의 증분(improvement)을 빼 준 것이 0.078 (7.82\%)이었다. 이러한 수치는 작을수록

Table 6. Gain summary of node \& Risk estimate

\begin{tabular}{cccc}
\hline \multicolumn{4}{c}{$\begin{array}{c}\text { Target variable: Multicultural acceptance } \\
\text { Growth method: CHAID }\end{array}$} \\
\hline Node & Gain (N) & Gain (\%) & Mean \\
\hline 3 & 754 & 52.4 & 15.15 \\
4 & 230 & 16.0 & 14.24 \\
2 & 455 & 31.6 & 13.96 \\
\hline & \multicolumn{4}{c}{ Risk statistics } \\
\hline Risk estimate & $0.078(7.82 \%)$ \\
SE of Risk estimate & .335 \\
\hline
\end{tabular}

더 선호되는 것으로 구축된 모형이 하나의 관찰치를 오분류(misclassification)할 확률이 7.82\%라는 것을 의미한다. 그리고 위험추 정치의 표준오차는 위험추정치가 이항분포의 성공확률을 나타내 는 모수로 간주될 경우 추정치에 계산되는 표준오차의 공식과 동 일하였다(Table 6).

\section{다문화청소년의 다문화 수용성 예측모델: 14살(중학교 2학년)} 의사결정나무모형 분석

국내 평균 만 14세(중학교 2학년) 다문화 청소년들의 다문화 수 용성을 예측하는 언어능력 변수에는 다문화 청소년의 한국어 능력 (듣기, 말하기, 읽기, 쓰기), 외국어 능력(다문화 청소년 어머니의 모 국어: 듣기, 말하기, 읽기, 쓰기), 그리고 다문화 청소년 어머니의 한 국어 능력(듣기, 말하기, 읽기, 쓰기)과 같은 12 가지 예측변수가 패 널이 만 11 세였을 때와 동일하게 포함되었다. 위의 12 개 예측변수 는 '전혀 못한다(1) 매우 잘한다(4)'로 측정하였다. 중지규칙(stopping rule)으로 가지를 이루는 마디의 개수를 의미하는 나무 깊이 (depth)를 최대 5 로 제한한 결과 4 마디 깊이 2 에서 정지하였다.

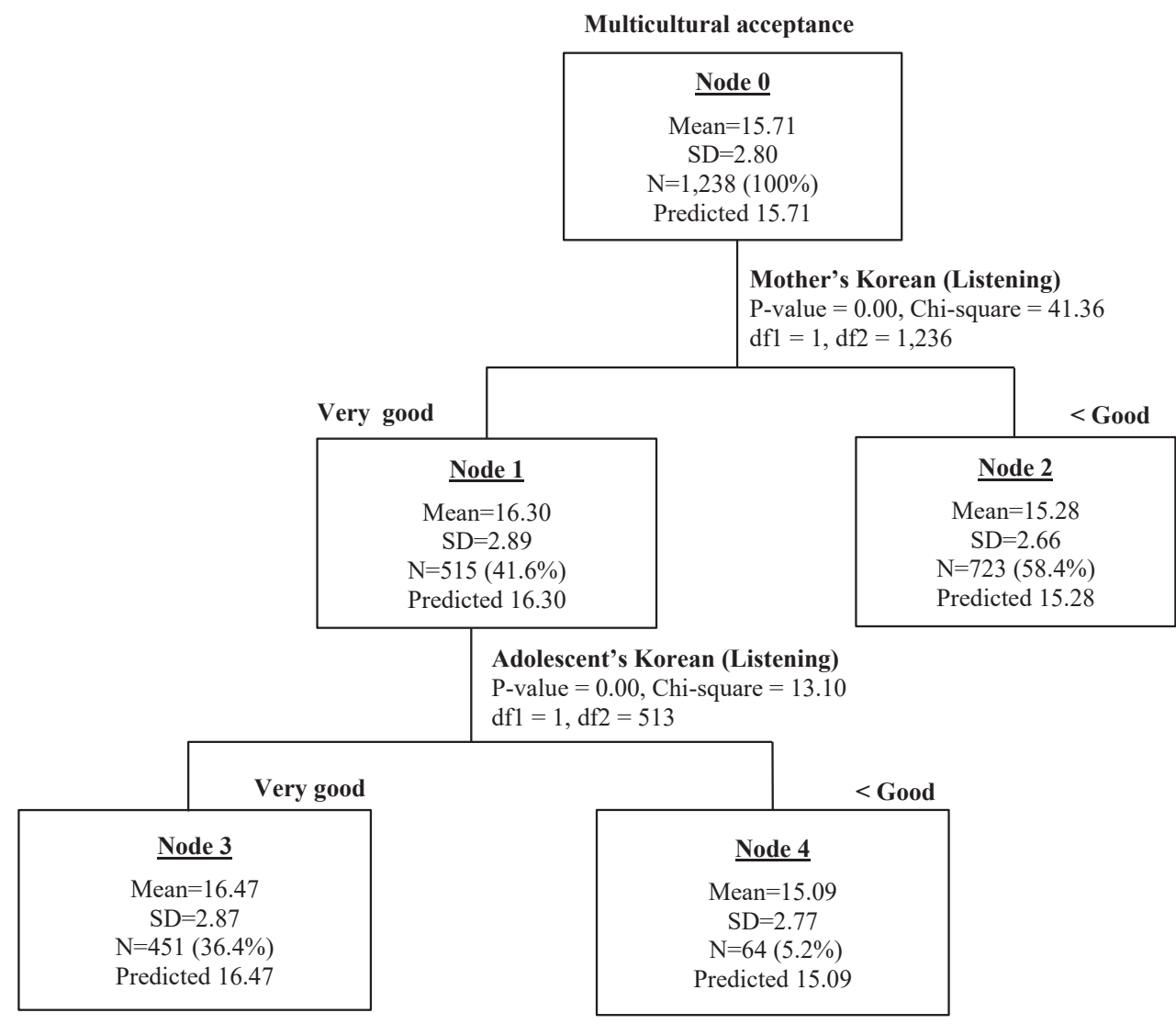

Figure 3. Decision tree predicting multicultural acceptance outcomes at average 14 years old in MAPS based on Korean and foreign language scores. 
Table 7. Gain summary of node \& Risk estimate

\begin{tabular}{cccc}
\hline \multicolumn{4}{c}{$\begin{array}{c}\text { Target variable: Multicultural acceptance } \\
\text { Growth method: CHAID }\end{array}$} \\
\hline Node & Gain (N) & Gain (\%) & Mean \\
\hline 3 & 451 & 36.4 & 16.47 \\
2 & 723 & 58.4 & 15.28 \\
4 & 64 & 5.2 & 15.09 \\
\hline & \multicolumn{3}{c}{ Risk statistics } \\
\hline Risk estimate & $0.075(7.50 \%)$ \\
SE of Risk estimate & .355 \\
\hline
\end{tabular}

분석결과 Figure 3에서 알 수 있듯이, 14세(중학교 2학년) 다문화 청소년의 다문화 수용성에 대한 첫 번째 분리는 다문화 청소년 어 머니의 한국어 듣기 능력에 의하여 이루어졌음을 알 수 있다. 본 연 구는 의사결정나무모형 알고리즘 중 $\mathrm{CHAID}$ 를 적용한 것으로 첫 번째 분리는 다문화 청소년 어머니의 한국어 듣기 능력에 대해 '매 우 잘한다'고 응답한 집단과 그렇지 않은 나머지 집단으로 구분하 여 이루어졌다. 다문화 청소년 중 어머니의 한국어 듣기 능력에 대 해 '매우 잘한다’고 응답한 집단의 다문화 수용성 평균은 16.30 , 나 머지 응답 집단(잘하는 편이다.와 ‘못하는 편이다.라고 응답한 대 상자)의 다문화 수용성 평균은 15.28 이었다(Figure 3). 즉, 어머니의 한국어 듣기 능력이 '매우 잘한다'에 속하는 다문화 청소년에게서 다문화 수용성에 대한 첫 번째 분리가 나타났으며 또한 이러한 집 단에게서 다문화 수용성이 더 높게 나타났다.

그리고 다문화 청소년의 다문화 수용성에 대한 두 번째 최적분 리는 다문화 청소년의 한국어 듣기 능력에 의해 분리되었다. 즉, 한 국어 듣기 능력이 매우 뛰어난 다문화 청소년 어머니를 두고 있으 며, 한국어 듣기를 매우 잘하는 다문화 청소년 집단에게서 다문화 수용성이 높게 나타났다(Figure 3).

\section{모형 평가}

다문화 수용성에 대한 의사결정나무에 대한 평가는 위험도표를 통해 진행하였다. 예측위험(risk estimate)은 자식마디에서의 집단 내 분산을 의미하는데, 전체분산에서 각 마디의 증분(improvement)을 빼 준 것이 0.075 (7.5\%)이었다. 이러한 수치는 작을수록 더 선호되는 것으로 구축된 모형이 하나의 관찰치를 오분류(misclassification)할 확률이 $7.5 \%$ 라는 것을 의미한다(Table 7).

\section{논의 및 결론}

본 연구는 다문화 청소년의 ‘다문화 수용성’을 목표변수로 하여
12 가지 '언어능력 예측변수(1) 다문화 청소년의 한국어 능력(듣기, 말하기, 읽기, 쓰기), (2) 다문화 청소년의 외국어 능력(다문화 청소 년 어머니의 모국어: 듣기, 말하기, 읽기, 쓰기), 그리고 (3) 다문화 청 소년 어머니의 한국어 능력(듣기, 말하기, 읽기, 쓰기)' 중 다문화 수용성을 예측하는 것은 어떠한 변수인지를 살펴보기 위한 것이었 다. 그리고 MAPS 대상자 중 한국어와 외국어 능력을 모두 평가한 2 차(평균 11 세, 초등학교 5학년)와 5차(평균 14 세, 중학교 2학년) 두 개의 패널 데이터를 이용하여 다문화 수용성을 예측하는 언어 변수에 대해 데이터 마이닝 의사결정나무모델 분석법을 적용하여 살펴보았다. 연구결과 다문화 청소년을 대상으로 진행된 종단추적 연구 데이터 중 다문화 수용성이라는 목표변수에 대해 2012년 초 등학교 5학년(11세, 2012년)과 2015년 중학교 2학년(14세) 연령변화 에 따라 다문화 수용성을 예측하는 언어변수에 대한 의사결정나 무모형은 차이가 있었다. 즉, 다문화 수용성을 예측하는 언어능력 변수들의 관련성을 살펴본 결과, 11 세 초등학교 5 학년 다문화 청소 년에게 있어서는 다문화 청소년의 한국어 말하기 능력과 다문화 청소년 어머니의 한국어 쓰기 능력이 다문화 수용성을 예측하는 것으로 나타났다. 그리고 14 세 중학교 2학년 다문화 청소년에게 있 어서는 다문화 청소년 어머니의 한국어 듣기능력과 다문화 청소년 의 한국어 듣기능력이 다문화 청소년의 다문화 수용성을 예측하 는 변수로서작용하였다.

이러한 주요 연구결과에 대하여 논의하면 다음과 같다. 첫째, 여 러 가지 언어를 알고 있는 것보다는 언어를 유창하게 잘 사용하는 정도가 다문화 수용성에 영향을 미치는 것으로 나타났다. 이와 같 은 연구결과는 이민자가정의 이스라엘 청소년을 대상으로 다문화 언어능력과 다문화 적응과의 관련성을 살펴본 Dewaele과 Stavans (2014)의 연구결과와 일치하는 것이었다. Dewaele과 Stavans (2014) 의 연구에서는 다문화 청소년 대상자들이 알고 있는 언어의 수가 교차문화 의사소통능력에 유의미한 영향을 미치지 못하였으나, 다 양한 언어를 사용하는 능력 수준이 문화적 공감능력과 같은 교차 문화 감수성에는 유의미한 영향을 미치는 것으로 나타났다. 그리고 이러한 연구결과에 대해, 저자는 교차문화 의사소통 능력이란 개 인의 언어문화 배경, 언어사용 능력과 같은 사회·문화적 배경요인에 의해 형성되는 것이라고 논의하였다. 국내의 경우는, 다문화 가정 내 다문화 청소년 어머니의 모국어를 다문화 청소년 대상자가 어느 정도 알고 있는지는 2 차년도나 5 차년도 자료 모두에서 다문화 수용 성에 대해 유의미한 영향을 미치지 않았다. 대신 다문화 청소년과 어머니의 한국어 능력이 다문화수용성을 예측하는 변수인 것으로 나타났다. 이러한 연구결과는 국내 다문화 가정 내의 의사소통 언 어가 주로 한국어로 이루어지고 있기 때문일 수도 있고, 다문화 청 
소년이 외국어(어머니의 모국어)에 대해 평균 이하의 능력을 가지 고 있기 때문일 수 있다. 하지만 결론적으로 우리가 다문화를 수용 하는 것은 외국어를 잘 사용하는 정도에 의해서가 아니라 대상자 의 모국어인 제 1 언어(한국어) 능력과 소수 다문화 대상자인 다문화 가정의 어머니의 제 2 언어(한국어) 능력이 영향을 미치는 것으로 나 타났다. 하지만 이러한 연구결과는 결혼이민자가정이 다수를 차지 하는 한국 다문화 사회에서만 나타나는 현상일 수도 있다.

둘째, 11 살 초등학교 5 학년 다문화 청소년의 다문화 수용성을 가 장 잘 예측하는 언어변수는 다문화 청소년의 한국어 말하기 능력 이었다. 이러한 연구결과는 11 세 다문화 청소년의 한국어 능력 평 가결과 듣기와 말하기 능력 모두가 '평균 상(4점 만점에서 평균 3.67)'의 능력으로 평가되었지만, 의사결정나무모형 분석결과 타인 과의 소통에 있어 중요하게 여겨지는 말하기 능력에 대해 '매우 잘 함’이라고 응답한 대상자들과 그렇지 않은 나머지 대상자들로 구 분이 이루어졌다. 그리고 다문화 청소년 중 자신의 한국어 말하기 능력에 대해 매우 잘한다고 응답한 집단 $(\mathrm{N}=984,68.4 \%)$ 의 다문화 수용성 평균은 14.94, 나머지 응답 집단('잘하는 편이다.'와 '못하는 편이다.'라고 응답한 대상자)(N=455, 31.6\%)의 다문화 수용성 평 균은 13.96 이었다(Figure 2). 즉, 한국어 말하기 능력이 '매우 잘한 다'에 속하는 다문화 청소년에게서 다문화 수용성에 대한 첫 번째 분리가 나타났으며 또한 이러한 집단에게서 다문화수용성이 더 높 게 나타났다. 이러한 연구결과는 다문화 청소년의 한국어 말하기 능력이 11 세에는 더 중요한 요인으로 작용하는 것이라 해석할 수 있다. 다문화를 수용한다는 것은 가정 내의 다문화 청소년 어머니 와의 의사소통이 잘 되어야 하는데, 이때 다문화 청소년의 말하기 언어능력이 많은 작용을 하며 다문화를 수용하는 심리적 거리에 도 유의미하게 작용하였을 것으로 예측할 수 있다.

셋째, 어머니의 한국어 사용 능력이 다문화 청소년의 다문화 수 용도에 영향을 미쳤다. 그리고 이러한 영향은 의사결정나무모형 분 석결과 다문화 청소년의 연령에 따라 차이를 보였다. 의사결정나무 모형 분석결과, 다문화 청소년이 11 세 초등학교 5 학년일 때 다문화 수용성에 대한 첫 번째 분리는 다문화 청소년이 자신의 한국어 말 하기 능력에 대해 ‘매우 잘한다’고 응답한 집단과 그렇지 않은 나머 지 집단으로 구분하여 이루어졌다. 그리고 두 번째 최적분리는 다 문화 청소년 어머니의 한국어 쓰기 능력에 의해 분리되었다. 즉, 한 국어 말하기를 매우 잘하는 다문화 청소년 중, 어머니의 한국어 쓰 기 능력이 잘하는 편(잘함, 매우 잘함)에 속하는 다문화 청소년 집 단 $(\mathrm{N}=754,52.4 \%)$ 의 다문화 수용성 평균은 15.15 , 나머지 응답 집 단('못하는 편이다.'와 '못한다'라고 응답한 대상자)( $\mathrm{N}=230,16 \%)$ 의 다문화 수용성 평균은 14.24 였다(Figure 2). 즉, 어머니의 한국
어 쓰기 능력이 '매우 잘함'에 속하는 것이, 다문화 청소년의 다문 화 수용성을 높이는 데 작용을 하였다. 이러한 연구결과는 다문화 청소년이 11 세일 때 다문화 청소년 어머니의 한국어 능력이 평균 이 하(2.4 미만, 전혀 못함 1점-매우 잘함은 4점)라는 점과 한국어 듣 기, 말하기, 읽기, 쓰기 4 가지 영역 중 쓰기에 대한 평균 점수가 2.06 이었다는 점을 감안하면, 다문화 청소년 어머니의 한국어 쓰기 능 력이 잘함 이상에 속하는 754명(52.4\%) 다문화 청소년 어머니의 말 하기, 듣기와 읽기는 더 잘 할 것으로 예상된다. 그러므로 쓰기 능력 이 잘함 이상인 다문화 청소년 어머니 집단은 한국어 능력이 매우 좋을 것으로 예측된다. 이렇게 한국어 능력이 매우 좋은 어머니는 다문화 청소년과의 상호작용을 원활하게 하였을 것으로 보이며 이 러한 영향이 다문화 수용성을 예측하는 변수로서 작용하게 되었 을 것으로 예상된다.

넷째, 14 살 중학교 2학년 다문화 청소년의 다문화 수용성을 가장 잘 예측하는 언어변수는 다문화 청소년 어머니의 한국어 듣기 능 력이었다. 의사결정나무모형 분석결과 다문화 수용성을 예측하는 첫 번째 분리는 다문화청소년 어머니의 한국어 듣기 능력에 대해 '매우 잘한다'고 응답한 집단( $\mathrm{N}=515,41.6 \%)$ 과 그렇지 않은 나머 지 집단 $(\mathrm{N}=723,58.4 \%)$ 으로 구분하여 이루어졌다. 다문화 청소년 중 어머니의 한국어 듣기 능력에 대해 '매우 잘한다'고 응답한 집단 의 다문화 수용성 평균은 16.30 , 나머지 응답 집단('잘하는 편이다', '못하는 편이다', '못한다'라고 응답한 대상자)의 다문화 수용성 평 균은 15.28 이었다(Figure 3). 즉, 어머니의 한국어 듣기 능력이 ‘매우 잘한다'에 속하는 다문화 청소년에게서 다문화 수용성에 대한 첫 번째 분리가 나타났으며 또한 이러한 집단에게서 다문화 수용성이 더 높게 나타났다. 이러한 결과는 다문화 청소년 어머니의 한국어 능력이 연구 대상자가 14 살이 된 시기에는 평균 상(평균 3.0 이상) 이었다는 점을 감안하면 어머니의 한국어 능력이 평균 이상의 수 준에 이르렀을 때는, 말하기와 읽기, 쓰기와 비교하였을 때 가장 쉬 운 영역으로 여겨지는 듣기 언어능력이 가장 뛰어난 다문화 청소년 어머니가 다문화 청소년들과 가장 소통을 잘 하는 것은 아닌가 예 측해 볼 수 있다. 그리고 이러한 다문화 청소년 어머니의 한국어 듣 기 능력은 다문화 청소년 자녀와의 의사소통 능력에 영향을 미쳤 을 것이다. 그리고 이러한 의사소통의 영향이 다문화 청소년의 다 문화수용도에까지 영향을 미쳤을 것으로 보인다.

다섯째, 14 살 중학교 2학년 다문화 청소년의 다문화 수용성에 대 한 첫 번째 분리는 다문화 청소년 어머니의 한국어 듣기 능력이었 다. 그리고 두 번째 최적 분리는 다문화 청소년의 한국어 듣기 능력 에 의해 분리되었다. 즉, 다문화 청소년 어머니의 한국어 듣기 능력 이 '매우 잘함'에 속하는 다문화청소년 중 한국어 듣기 능력이 '매 
우 잘함' 수준인 다문화 청소년 집단 $(\mathrm{N}=451,36.4 \%)$ 의 다문화 수 용성 평균은 16.47 , 나머지 응답 집단('잘하는 편이다, '못하는 편이 다', '못한다'라고 응답한 대상자)(N=64,5.2\%)의 다문화 수용성 평균은 15.09였다(Figure 3). 즉, 다문화 청소년 어머니와 다문화 청 소년 모두 동일하게 사용하는 한국어에 있어 가장 쉽게 여겨지는 '듣기' 능력이 뛰어날수록 다문화 수용도가 높았다. 이러한 연구결 과는 다문화 청소년이 14 세 때는 대상자의 한국어 능력도 3.5 이상 의 '매우 잘함'의 수준이며 어머니의 한국어도 3.0 이상의 '잘함' 수 준인 것을 감안하면 한국어 능력이 일정 수준 즉, 잘함 이상일 때는 듣기 언어 능력이 다문화 수용도를 예측하는데 가장 중요한 능력 영역으로 작용한다고 예측할 수 있다.

여섯째, 이번 연구결과는 현재 국내 다문화 수용성 연구에 있어 일반 대학생을 대상으로 외국어능력이 다문화 수용성에 유의미한 영향을 미쳤음을 살펴본 연구와는 차별성을 갖는다(Park \& Won, 2010; Joo \& Park, 2019). 위에서 언급한 연구결과들은 다문화 청소 년의 다문화수용성을 예측하는 변수로써 다문화 청소년과 어머니 의 4 가지 언어기능 능력(한국어 듣기, 말하기, 읽기, 쓰기)의 주요 변 수가 11세와 14세때에 다르게 나타났음을 설명하였다. 구체적으로 구분하여 보면 11세때는 다문화 청소년의 한국어 말하기 능력과 다문화 청소년 어머니의 한국어 쓰기 능력에 의해 주로 다문화 수 용성이 예측되었다. 그리고 14 세가 되었을 때는 다문화 청소년 어머 니의 한국어 듣기 능력과 다문화 청소년의 한국어 듣기 능력에 의 해 주로 다문화 수용성이 예측되었다. Park과 Won (2010), 그리고 Joo와 Park (2019)은 일반 대학생들을 대상으로 외국어인 영어 능 력이 다문화수용성에 유의미한 영향을 미치는지를 살펴보았다. 하 지만 본 연구는 일반가정과는 다른 언어.문화환경을 가진 다문화 청소년을 대상으로 한국어와 외국어(다문화 청소년 어머니의 모국 어) 중 다문화 수용성을 예측하는데 유의미하게 작용하는 언어변 수를 찾는 것이었다. 그리고 그 결과 한국어 말하기, 듣기, 쓰기 능 력이 다문화 수용성을 유의미하게 예측하는 변수로 작용하고 있 음을 확인하였다.

일곱째, 이전 국내의 언어와 다문화 수용성 관련 연구와 본 연구 결과 차이에 대해 논의하면 다음과 같다. 1) 일반과 다문화 집단 간 의 다문화 수용성 정도에 영향을 미치는 것은 언어라는 공통점을 가지고 있다. 하지만 일반 집단에서는 영어라는 제 2 언어 능력이 다 문화 수용도에 영향을 미쳤지만, 다문화 집단은 제 1 언어인 한국어 능력이 다문화수용성에 유의미한 영향을 미치는 변수로써 작용하 였다. 즉, 언어문화 집단에 따라 다문화 수용도에 영향을 미치는 언 어가 다를 수 있다고 볼 수 있다. 2) 제 1 과 2 언어의 차이가 나타난 것 은 한국적 다문화 가정의 특징일 수도 있다. 국외의 경우는 타국에
정착하기 위한 이민 또는 이주노동자가 주요 다문화 사회를 구성 하는 집단이라면, 국내는 한국인 남성과 결혼하여 한국에 입국하 는 중국 또는 동남아 여성 결혼이민자가 국내 전체 다문화가구 30 만 6,995가구의 대부분(85.7\%)을 차지하고 있으며 주 다문화 사회 를 구성하고 있다(Korean statistical information service, Statistics Korea, 2020). 즉, 한국의 다문화 가정은 한국어를 사용하는 아버 지와 소수언어를 사용하는 어머니로 구성되어 있다. 이러한 언어환 경 요인으로 국내 다문화가정 아동 및 청소년은 한국어 능력이 더 우선시되어 사용되고 있으므로 다문화 가정 어머니의 소수 언어 능력에 대해서는 깊이 있는 평가가 이루어지고 있지 않고 있다. 이 처럼 한국어가 우선시되는 언어환경에서는 제 1 언어인 한국어가 다 문화 청소년의 다문화 수용성에 영향을 미치는 변수로 작용했을 가능성이 크다고 여겨진다. 3) 일반 대상자와 다문화 대상자의 제2 언어는 서로 다를 수 있다. 이번 연구의 대상자인 초등학교 5 학년과 중학교 2학년 다문화 청소년들은 학교에서 정규수업을 통해 그리 고 개인 사설학원을 통해 영어에 대해 지속적으로 꾸준하게 또한 중요하게 수업이 진행되고 있다. 다른 언어를 배우고 있는 일부 대 상자를 제외하고는 일반 대상자들의 제 2 언어는 영어가 될 수 있다. 하지만 다문화 청소년 중에서도 어머니가 모국어로 의사소통을 자 녀와 하는 가정에서는 제 2 언어는 다문화 청소년 어머니의 모국어 가 될 수 있다. 그러므로 기존의 언어와 다문화수용성 간의 관련성 을 살펴본 연구와 이번 연구는 제 2 언어에 대한 구분이 명확하지 않 을 수 있다. 이러한 부분이 기존연구에서는 영어능력이 다문화 수 용성에 유의미한 영향 변수로 나타났지만 본 연구에서는 한국어만 이 다문화수용성에 유의미한 변수로 작용한 것일 수도 있다.

외국의 경우 Bae (2012)는 한국의 일반 초등학교 5-6학년과 중학 교 1-2학년 272명을 대상으로 영어(제2언어) 읽기와 쓰기 능력과 교 차문화 감수성을 측정하여 이들 변수들의 관련성을 살펴보았다. 연구결과 영어 읽기와 쓰기 능력이 높은 청소년일수록 교차문화 감수성이 유의미하게 높게 나타났다. 이는 외국어 능력이 다문화 수용성과 관련이 있었다는 국내 연구결과와 유사한 결과였다. 언 어와 교차문화 수용성과의 관련성을 살펴본 또 다른 국외 연구에 있어, Zhang (2019)은 영어를 전공하고 있는 중국 대학생 30명을 대상으로 영어(제 2 언어) 쓰기 구문 문법능력이 교차문화 의사소통 능력에 유의미한 영향을 미치는 것을 확인하였다. 이러한 결과는 이번 연구에 있어 다문화 청소년 어머니의 한국어(제 2 언어) 쓰기 능력이 11 세 다문화 청소년의 다문화 수용성에 유의미한 영향을 미치는 변수로 확인된 결과와 유사하다고 볼 수 있다. 물론 다문화 청소년의 외국어 쓰기 능력이 다문화 수용성에 영향을 미친 것은 아니지만, 대상자의 어머니처럼 주 의사소통 대상자의 구문능력과 
같은 쓰기 언어능력 또한 교차문화 의사소통능력과 관련이 있음 을 확인하였다. 하지만 서로 다른 다양한 언어와 문화와 관련된 이 러한 연구 변수들을 해석함에 있어 조심스러움이 있다.

여덟째, 4 가지 언어기능을 정보처리과정 측면에서 구분하여 살 펴보면, 듣기와 읽기가 정보의 수집과 해석에 관한 것이라면 말하 기, 쓰기는 사고과정의 결과와 표현에 관한 것이다. 그리고 듣기와 읽기를 통해 상대방의 의중과 문장의 핵심을 파악할 줄 알아야 효 과적인 말하기가 가능하다. 말을 할 때는 상대방이 듣기 편한 발성 과 표현의 강약을 조절할 수 있어야 하며 필요에 따라서는 부드럽 게 또는 정확하게 말하고, 표정과 손짓도 함께 표현의 수단으로 잘 이용할 수 있어야 한다. 즉, 말하기는 듣기와 읽기가 바탕이 된 의사 소통의 종합적 측면을 의미한다. 쓰기는 말하기보다 더 어려운 정 보처리 능력으로 구문능력을 좀 더 필요로 하며 글자를 쓴다는 것 은 문장을 구성하는 좀 더 논리적 측면과 쓰기에 대한 기술적 훈련 이 요구되는 측면이다. 그리고 언어의 정보처리 측면을 고려하여 언 어능력과 다문화 수용성과의 관련성 연구결과를 해석하여 보면 다문화 청소년이 11 살 초등학교 5 학년일 때는 다문화 청소년의 한 국어 말하기, 다문화 청소년 어머니의 한국어 쓰기 변수가 다문화 수용성을 예측하는 변수로 작용하였다. 이러한 연구결과는 다문 화 가정 청소년과 어머니가 서로 사고과정을 언어로 표현할 수 있 는 능력이 다문화를 수용하는데 유의미한 변수로 작용하고 있다 고 해석할 수 있다. 그리고 다문화 청소년이 14 살 중학교 2학년일 때 는 다문화 청소년 어머니의 한국어 듣기, 다문화 청소년의 한국어 듣기 변수가 다문화 수용성을 예측하는 변수로 작용하였다. 이러 한 결과는 중학교 2 학년 때는 초등학교 5 학년일 때와는 달리 상대 방의 정보를 잘 수집하는 능력이 다문화를 수용하는데 유의미한 변수로 작용하고 있다고 해석할 수 있다.

이상의 연구결과를 통해, 본 연구에서 시사하는 바는 다음과 같 다. 첫째, 본 연구는 현재 교차문화 의사소통 능력 또는 다문화 수 용성이 외국어 능력 또는 외국어 학습과 관련되어 있다는 이전의 연구들(Bae, 2012; Mao, 2015; Park \& Won, 2010; Joo \& Park, 2019)과는 달리 외국어가 아닌 대상자의 모국어 능력이 다문화 수 용성을 예측하는 중요한 변수로 작용하고 있음을 확인하였다. 일 반적으로 교차문화 의사소통 또는 다문화 수용성이란 다른 문화 배경의 언어를 잘 하는 것과 관련이 있는 것으로 보이지만 모국어 에 대한 언어 능력이 더 영향을 미치는 변수로 작용하고 있다는 것 을 이번 연구결과는 제시하여 주고 있다.

둘째, MAPS에 적용된 다문화 수용성은 다른 문화에 대한 사회 적 거리 측정과 관련된 개념이 적용된 과제였다. 이에 이번 연구는 국외 교차문화 의사소통 능력과 관련된 다수의 사회적 거리 연구
가 사회 계층에 따른 사회적 거리 연구였다는 것(Akerlof, 1997; Hipp, 2006)과 달리, 다문화 청소년들의 모국어인 한국어와 어머니 의 모국어인 외국어 능력, 그리고 다문화 청소년 어머니의 한국어 언어능력이 다문화 청소년의 타 문화에 대한 사회적 거리를 예측하 는데 영향변수로 작용하고 있는지를 살펴보았다는 것에 의미가 있 다. 그리고 Salzinger 등(1970)은 언어적 행동과 사회적 거리(Verbal behavior and social distance) 연구에 있어 사람들은 일반적으로 의사소통이 가능한 상대자에 대하여 더 많은 시간을 보내고 친밀 한 사회적 거리를 느낀다는 연구결과는, 이번 연구에서 다문화 청 소년과 다문화 청소년 어머니 모두의 한국어 능력이 사회적 거리를 예측하는 변수로 작용하였다는 연구결과와 어느 정도 일치하는 결 과였다.

셋째, 다문화 수용성 연구 대상자는 대부분 다수의 일반인을 대 상으로 다문화 소수 집단에 대한 다문화 수용성을 살펴보는 연구 가 대부분이었다. 하지만 이번 연구는 다문화 청소년이 소수의 다 른 문화배경 사람에 대한 다문화 수용성을 살펴본 연구였다는 점 에 있어서 차별성이 있었다.

넷째, 이번 연구는 대상자의 연령을 11살과 14살로 구분하여 다 문화 수용성을 예측하는 언어변수를 살펴보았다. 초등학교 5 학년 인 11살과 중학교 2 학년인 14 살 다문화 청소년의 언어 능력이란 학 습을 위한 부분은 완성이 된 부분으로 여겨질 수 있다. 하지만 좀더 깊이 있게 생각해보면 우리가 일상생활에서 사용하는 언어의 듣기, 말하기, 읽기와 쓰기와 같은 4 가지 기능은 담화와 화용의 언어사용 측면이 모두 포함된 의사소통 영역으로 발달의 한계를 정하는 것 은 어려운 일이다. 그러므로 이번 연구에 있어 다문화 청소년을 대 상으로 한국어 능력을 4 가지 영역(듣기, 말하기, 읽기, 쓰기)으로 구 분하여 측정한 것은 학습적 측면의 언어능력을 측정한 것이 아니 라, 다문화 청소년의 의사소통능력을 4 가지 언어기능인 듣기, 말하 기, 읽기, 쓰기로 나누어 평가한 것으로 볼 수 있다. 그러므로 4 가지 언어능력이 다문화수용성을 어떻게 예측하는지는 연령에 따라 변 화할 가능성이 있다. 이러한 변화 가능성에 대한 의문점을 살펴보 았다는데 있어 이번 연구는 의미가 있다.

마지막 다섯째, 다문화 수용성과 언어와의 관련성을 패널데이터 를 이용하여 데이터 마이닝 의사결정나무모형 분석을 통해 살펴본 것은, 점점 많아지는 다문화 데이터에 대한 새로운 분석적 시각을 제시하였다는 점에 있어 의의가 있다. 즉, 실험연구처럼 통제된 상 황에서 연구가 진행되어 예측된 실험설계에 의해 연구분석이 진행 되는 연구가 아닌 공공데이터를 다루는 연구방법은 차별되어야 한 다. 데이터에 대한 새로운 연구방법 접근은 데이터가 의미 있는 연 구로 발전할 수 있는 계기가 되었다. 
그리고 이번 연구결과에서 확인한 연구결과를 토대로 본 연구가 갖는 제한점을 밝히며 후속 연구에 대한 제언을 제시하면 다음과 같다. 첫째, 이번 연구 결과는 다문화 수용성 5 개 문항에 대한 평균 다문화 수용성에 대해 관찰되는 분산의 비율이 적기 때문에 결론 을 확대 해석하기는 어렵다. 왜냐하면 다문화 수용성에 관여되는 어떤 중요한 요인이 간과되었을 지 또는 듣기, 말하기, 읽기와 쓰기 와 같은 언어능력 측정 연속형 변수에 대해 4지형(4점 척도) 분리를 함으로써 생기는 정보의 손실 등으로 모형의 정확도가 떨어졌을지 도 모르기 때문이다. 둘째, 이번 연구에서 예측변수로 작용한 언어 능력 12 개의 변수는 모두 주관적인 개인의 관점에서 스스로의 능 력을 또는 어머니의 언어능력을 4 점 척도로 평가한 것들이었다. 하 지만 이러한 주관적 평가방법은 신뢰도의 문제를 가지고 있다. 이 에 다음 연구에서는 소규모 집단을 대상으로 타당화가 진행된 언 어검사도구를 활용하여 대상자들의 언어능력을 평가하는 것이 요 구된다. 본 연구자도 타당화가 완료된 언어검사도구를 활용하였을 때의 연구결과가 이번 MAPS의 데이터 분석 연구결과와 동일할지 가 궁금하다.

\section{REFERENCES}

Ahn, S. S., Kim, Y., Ma, K. H., Moon, H. Y., \& Lee, M. J. (2015). A national survey on multicultural water availability (research report 2015-55). Seoul: Ministry of gender equality and family.

Akerlof, G. A. (1997). Social distance and social decisions. Econometrica, 65(5), 1005-1027.

Bae, J. (2012). Developing general literacy ability and intercultural sensitivity through English literacy instruction: using global literature for Korean EFL learners (Doctoral dissertation). University of Kansas, Kansas, USA.

Bennett, M. J. (2004). Developing intercultural sensitivity. In D. Landis, J. M. Bennett, \& J. Bennett (Eds.), Handbook of intercultural training (3rd ed.) (pp. 147-165). Thousand Oaks, CA: Sage.

Benson, S. J. (2016). Social ties and adaptation in Asian students. New Zealand Sociology, 31(7), 48-67.

Bogardus, E. S. (1947). Measurement of personal-group relations. Sociometry, 10(4), 306-311.

Bogardus, E. S. (1971). What does social distance measure? Phi Kappa Phi Journal, 51(2), 49-54.

Brown, E. L. (2004). The relationship of self-concepts to changes in cultural diversity awareness: implications for urban teacher educators. The Urban Review, 36(2), 119-145.
Chen, G. M., \& Starosta, W. J. (1996). Intercultural communicative competence: a synthesis. Annals of the International Communication Association, 19(1), 353-383.

Chen, G. M., \& Starosta, W. J. (2000). The development and validation of the intercultural communication sensitivity scale. Human Communication, 3 , $1-15$.

Cushner, K., \& Brislin, R. W. (1996). Intercultural interactions: a practical guide (2nd ed.). Thousand Oaks, CA: Sage.

Davis, S. L., \& Finney, S. J. (2006). A factor analytic study of the cross-cultural adaptability inventory. a factor analytic study of the cross-cultural adaptability inventory. Educational and Psychological Measurement, 66(2), 318330.

Dewaele, J. M., \& Stavans, A. (2014). The effect of immigration, acculturation, and multicompetence on personality profiles of Israeli multilinguals. International Journal of Bilingualism, 18(3) 203-221.

Giles, M., \& Evans, A. S. (1990). Social distance: in group integration and perceived external threat. Journal of Black Studies, 14(1), 30-35.

Ham, H. J., \& Kim, J. W. (2018). Development of an educational program based on world traditional fairy tales to improve multicultural acceptability of upper grade elementary school students. Multicultural Education Studies, 11(1), 109-132.

Hammer, M. R., Bennett, M. J., \& Wiseman, R. (2003). Measuring intercultural sensitivity: the intercultural development inventory. Intercultural Journal of Intercultural Relations, 27(4), 421-443.

Hipp, J. R. (2006). Social distance and social change: how neighborhoods change over time (doctoral dissertation). University of North Carolina, North Carolina, USA.

Hong, K. H. (2014). The impact of multicultural education program in the daily life schedule on children's multicultural acceptability and pro-social behavior. Journal of Korean Childcare and Education, 10(6), 313-332.

Hraba, J., Radloff, T., \& Gray-Ray, P. (1999). A comparison of black and white social distance. Journal of Social Psychology, 139(4), 536-539.

Jin, B. K., \& Park, H. S. (2018). A study on the multicultural acceptance among Korean soldiers. Crisisonomy, 14(4), 133-150.

Joo, M., \& Park, S. M. (2019). A study on English learning and multicultural acceptance: focused on college students. English Language \& Literature Teaching, 25(2), 113-132.

Jung, J., Kim, Y. S., \& Hong, J. H. (2014). A study on multicultural recognition of secondary students participating in the multicultural literacy program. The Journal of Yeolin Education, 22(2), 19-41. 
Jung, M. H., \& Park, W. B. (2012). A study on the determinants of multicultural acceptance of multicultural people. Journal of International Trade \& Commerce, 8(2), 355-370.

Kang, M. H., \& Ko, H. (2019). Effects of pre-service secondary teachers' perception and acceptability of multiple cultures on multicultural teaching efficacy. Journal of Learner-Centered Curriculum and Instruction, 19(15), 1-24.

Kass, G. V. (1980). An exploratory technique for investigating large quantities of categorical data. Journal of the Royal Statistical Society: Series C (Applied Statistics), 29(2), 119-127.

Kelly, C., \& Meyers, J. (1995). The cross-cultural adaptability inventory manual. Minneapolis, MN: National Computer System.

Kim, K. S., \& Yun, S. K. (2019). The impact on multicultural education competency of preparing young children teachers' human tights awareness. Multicultural acceptance, and multicultural teaching efficacy. Journal of Learner-Centered Curriculum and Instruction, 19(14), 137-157.

Kim, M. J., \& Chung, O. B. (2010). Development and validation of a multicultural acceptance inventory for Korean children. The Korean Journal of the Human Development, 17(4), 69-88.

Kong, J. S., \& Chang, I. (2018). The effects of a debate-based multicultural education program on multicultural awareness and empathy. The Journal of Education, 38(4), 271-292.

Kwak, Y. K., \& Yang, Y. M. (2017). The effects of physical activities on middle school students' multicultural acceptance: focusing on self-esteem as a mediator. Multicultural Education Studies, 10(2), 147-170.

Kwon, H. J., \& Lee, K. Y. (2018). An analysis of the structural relationship among multicultural education experience, multicultural climate, multicultural efficacy, and multicultural acceptability perceived by multicultural education-oriented elementary schools' students. Journal of Korean Practical Arts Education, 31(3), 197-220.

Kwon, J. H., \& Lee, S. H. (2015). Testing models of relation to parents" rearing attitudes, interpersonal relationship ability, and multicultural acceptance of adolescent. Forum for Youth Culture, 44, 7-32.

Lauman, E. O. (1965). Subjective social distance and urban occupational stratification. American Journal of Sociology, 71(1), 26-36.

Law, S. G., \& Lane, D. S. (1987). Multicultural acceptance by teacher education students: a survey of attitudes toward 32 ethnic and national groups and a comparison with 60 years of data. Journal of Instructional Psychology, 14(1), 3-9.

Lee, J. H., \& Kim, K. K. (2012). Determinants of Koreans' multicultural acceptability: focusing on the effect of educational attainment. Korean Jour- nal of Sociology of Education, 22(3), 163-192.

Lee, J. S., Kang, Y. S., Park, S. G. (2018). Determinants of multicultural acceptability of moral curriculum for 3rd and 4th-grade Students of elementary schools. The Journal of Multicultural Society, 11(2), 135-170.

Lee, H. Y. (2019). Professor Lee Hoon-Young's research methodology (2nd ed.). Seoul: Book publishing Chung-ram.

Lee, M. Y., Sapp, S. G., \& Ray, M. C. (1996). The reverse social distance scale. Journal of Social Psychology, 136(1), 17-24.

Loo, R., \& Shiomi, K. (1999). A structural and cross-cultural evaluation of the inventory of cross-cultural sensitivity. Journal of Social Behavior and Personality, 14(2), 267-278.

Mao, Y. (2015). Investigating Chinese migrants' information-seeking patterns in Canada: media selection and language preference. Global Media Journal, 8(2), 113-131.

Min, M. S., Ahn, S. S., Kim, Y. S., Kim, G. M., Cho, Y. K., \& Ryu, J. A. (2010). The development of Korean multi-cultural water-soluble diagnostic tools. Seoul: Committee for social integration.

Min, M. S., Ahn, S., Kim, Y. S., Cho, H. Y., \& Lee, M. J. (2012). A study on the availability of multicultural water for teenagers (research report 2012-51). Seoul: Ministry of gender equality and family.

Montagliani, A., \& Giacalone, R. A. (1998). Impression management and cross-cultural adaption. The Journal of Social Psychology, 138(5), 598-608.

Munroe, A., \& Pearson, C. (2006). The Munroe multicultural attitude scale questionnaire: a new instrument for multicultural studies. Educational and Psychological Measurement, 66(5), 819-834.

Park, H. S. (2016). A Comparison of Chinese and Korean university students' perceptions of Koreans' multicultural receptivity. Studies in Humanities and Social Sciences, 53, 41-64.

Park, H. S., \& Won, M. S. (2010). An exploration of variables related with multicultural receptivity of Korean university students. The Korean Journal of Educational Psychology, 24(2), 303-325.

Park, I. A. (2013). A study on the development of educational program and its effects to improve the receptivity to multi-culture of university students majoring in social welfare. Korean Journal of Social Welfare Education, 23, 201-223.

Patterson, P. K. (2006). Effect of study abroad on intercultural sensitivity (Doctoral dissertation). University of Missouri, Columbia, USA.

Risner, M. E. (2011). Developing intercultural competence through blended learning: the role of peer interaction (doctoral dissertation). University of Florida, Florida, USA. 
Salzinger, K., Hammer, M., Portoy, Polgar, S., \& Polgar, S. K. (1970). Verbal behaviour and social distance. Language and Speech, 13(1), 25-37.

Sarwari, A. Q., \& Abdul Wahab, M. N. (2017). Study of the relationship between intercultural sensitivity and intercultural communication competence among international postgraduate students: a case study at University Malaysia Pahang. Cogent Social Sciences, 3(1), 1-11.

Scandrette, O. C. (1958). Social distance and degree of acquaintance. Journal of Educational Research, 51(5), 367-372.

Seol, E. J., \& Chung, O. B. (2012). The effects of parenting behaviors on the multicultural acceptance levels of Korean children. The Korean Journal of the Human Development, 19(2), 91-114.

Statistics Korea, Korean statistical information service (KOSIS, http://kosis. $\mathrm{kr} / \mathrm{index} / \mathrm{index} . \mathrm{do})$

The Korean Ministry of Education. (2019) Education Basic Statistics Table (KMOE, https://www.moe.go.kr/boardCnts/list.do?boardID=351\&m= 0310\&s=moe)

The Korea Youth Policy Institute. (2011). Multicultural Youth Panel Survey: 1 st to 6 th year youth survey table. Seoul: Korea Youth Policy Institute.

Triandis, H. C., \& Triandis, L. M. (1962). A cross-cultural study of social distance. Psychological Monographs: General and Applied, 76(21), 1-21.
Uttley, C. M. (2008). Multicultural awareness in college freshmen: an examination of measures and interventions (Doctoral dissertation). University of Rhode, Isladn, USA.

Van der Zee, K. I., \& Van Oudenhoven, J. P. (2000). The multicultural personality questionnaire: a multidimentional instrument of multicultural effectiveness. European Journal of Personality, 14(4), 291-309.

West, L. C. (2009). Evaluating the intercultural sensitivity scale with counselors in international school (doctoral dissertation). Regent University, Virginia, USA.

Westie, F. R. (1959). Social distance scale: a tool for the study of stratification. Sociology and Social Research, 43(4), 251-258.

Yang, J. N., Choi, E. J., Moon, R. Y., Park, G. Y., \& Park, S. H. (2011). A study on how social work student's self-efficacy and advocacy effects multicultural receptiveness. Korean Journal of Social Welfare Education, 12(1), 24-47.

Yang, K. M., \& Jung, J. K. (2008). A study on the promotion of multicultural education for youth for social integration. Seoul: Korea youth policy institute

Zhang, M. (2019). Correlation study on grammatical sensitivity test indexes in intercultural communication. Revista de Cercetare si Interventie Socuala, $65,260-271$. 


\section{국문초록}

\section{다문화 청소년의 다문화 수용성 예측요인에 대한 데이터 마이닝 의사결정나무모형 분석: 한국어와 어머니 모국어에 대한 4가지 언어사용 능력(듣기, 말하기, 읽기, 쓰기)을 중심으로 \\ 이은주}

이화여자대학교 언어병리학과

배경 및 목적: 언어와 밀접한 관련을 보이는 교차문화와 다문화에 대한 연구에 있어 다문화 수용성과 한국어와의 관련성에 대한 다문 화 집단을 대상으로 한 연구는 찾아볼 수 없었다. 이에 한국어와 외국어(다문화 청소년의 어머니 모국어)에 다양하게 노출되어 있는 다 문화 청소년을 대상으로 다문화 수용성에 영향을 미치는 요인으로서 한국어와 외국어 4 가지 기능(듣기, 말하기, 읽기, 쓰기)의 언어사 용 능력에 대한 영향을 살펴보았다. 방법: 한국청소년정책연구원의 다문화청소년패널조사(MAPS)의 2차(2012년, 만11세) 1,439명과 5 차(2015년, 만 14세) 1,238 명 다문화 청소년을 대상으로 다문화 수용성을 예측하는 언어능력(다문화 청소년의 한국어와 외국어, 다문 화 청소년 어머니의 한국어)의 관계를 살펴보기 위하여 의사결정나무모형 분석을 실시하였다. 결과: 만 11 세 초등학교 5 학년 다문화 청 소년에게 있어서는 다문화 청소년의 한국어 말하기 능력과 다문화 청소년 어머니의 한국어 쓰기 능력이 다문화 수용성을 예측하는 것 으로 나타났다. 그리고 만 14 세 중학교 2 학년 다문화 청소년에게 있어서는 다문화 청소년 어머니의 한국어 듣기능력과 다문화 청소년의 한국어 듣기능력이 다문화 청소년의 다문화 수용성을 예측하는 변수로서 작용하였다. 논의 및 결론: 우리가 다문화를 수용하는 것은 외국어 능력에 의해서가 아니라 다문화 청소년의 한국어 능력과 소수 다문화 대상자(이번 연구에서는 다문화 가정의 어머니)의 한국 어 능력이 주요 영향을 미치는 것으로 나타났다. 하지만 이러한 연구결과는 결혼이민자가정이 다수를 차지하는 한국 다문화 사회 특유 의 현상일 수도 있으므로 결과 해석에 있어 조심스러운 부분이 있다.

핵심어: 다문화청소년패널조사(MAPS), 다문화 수용성, 언어 유창성, 나무의사결정 분석, 결혼이민자가정

본 연구는 한국연구재단 BK21 플러스의 지원을 받았음(2020).

\section{참고문헌}

강미희, 고현(2019). 중등예비교사의 다문화인식과 다문화수용성이 다문화 교수효능감에 미치는 영향 학습자중심교과교육연구, 19(15), 1-24. 교육부, 2019년 교육기본통계표 전국초등학생 지역별 비율(https://www.moe.go.kr/boardCnts/list.do?boardID =351\&m=0310\&s=moe). 공진실, 장인실(2018). 대립토론에 근거한 다문화교육 프로 그램이 초등학생의 다문화인식과 공감능력에 미치는 영향. 교육논총, 38(4), 271-292. 곽윤경, 양영미(2017). 중학생의 체육활동 참여가 다문화 수용성에 미치는 영향: 자아존중감의 매개효과를 중심으로. 다문화교육연구, 10(2), 147170.

권재환, 이선희(2015). 청소년의 부모양육태도, 대인관계능력과 다문화수용성의 관계모형 검증. 청소년문화포럼, 44, 7-32.

권하정, 이기용(2018). 다문화교육 중점학교 초등학생이 지각하는 다문화교육 경험, 다문화 분위기, 다문화 효능감, 다문화 수용성 간의 구조 관계 분 석. 한국실과교육학회지, 31(3), 197-220.

김갑순, 윤상기(2019). 예비유아교사의 인권의식, 다문화 수용성, 다문화 교수효능감이 다문화 교육역량에 미치는 영향. 학습자중심교과교육연구, 19(14), 137-157.

김미진, 정옥분(2010). 아동의 다문화 수용성 척도개발 타당화 연구. 인간발달연구, 17(4), 69-88.

민무숙, 안상수, 김이선, 김금미, 조영기, 류정아(2010). 한국형 다문화수용성 진단도구개발. 서울: 사회통합위원회.

민무숙, 안상수, 김이선, 선보영, 이명진(2012). 청소년의 다문화수용성 조사 연구 (연구보고 2012-51). 서울: 여성가족부.

박인아(2013). 사회복지학 전공 대학생의 다문화 수용성 향상을 위한 교육프로그램 개발과 효과성 연구. 한국사회복지교육, 23, 201-223. 
박혜숙(2016). 국내 중국인 유학생이 느끼는 한국인의 다문화수용성 수준과 한국인 대학생의 다문화수용성 수준 비교. 인문사회과학연구, 53, 41-64. 박혜숙, 원미순(2010). 대학생들의 다문화수용성과 관련변인 탐색. 교육심리연구, 24(2), 303-325.

설은정, 정옥분(2012). 부모의 양육행동이 아동의 다문화수용성에 미치는 영향. 인간발달연구, 19(2), 91-114.

안상수, 김이선, 마경희, 문희영, 이명진(2015). 국민 다문화수용성 조사 연구(연구보고서 2015-55). 서울: 여성가족부.

양계민, 정진경(2008). 사회통합을 위한 청소년 다문화교육 활성화방안 연구. 서울: 한국청소년정책연구원.

양정남, 최은정, 문란영, 박건영, 박순희(2011). 자기효능감, 사회복지옹호태도가 사회복지전공대학생의 다문화 수용성에 미치는 영향. 한국사회복지

교육, 12(1), 24-47.

이자형, 김경근(2012). 한국인의 다문화수용성 결정요인 분석: 교육수준의 영향을 중심으로. 교육사회연구, 22(3), 163-192.

이진선, 강영숙, 박시균(2018). 초등 3,4 학년의 도덕 교과과정 다문화수용성 분석. 다문화사회연구, 11(2), 135-170.

이훈영(2019). 이훈영교수의 연구조사방법론 (제2판). 서울: 도서출판 청람.

정명희, 박외병(2012). 다문화인의 다문화 수용성 결정요인에 관한 연구. 무역연구, 8(2), 355-370.

정지현, 김영순, 홍정훈(2014). 다문화 리터러시 교육 프로그램 참여 고등학생의 다문화 인식에 관한 연구. 열린교육연구, 22(2), 19-41.

주미란, 박성만(2019). 영어학습과 다문화수용성에 관한 연구: 대학생 중심. 영어어문교육, 25(2), 113-132.

진병규, 박효선(2018). 한국군 장병의 다문화수용성에 관한 연구. Crisisonomy, 14(4), 133-150.

통계청, 국가통계포털(http://kosis.kr/index/index.do)

한국청소년정책연구원 (2011). 다문화청소년패널조사: 1-6차년도 청소년용 조사표. 서울: 한국청소년정책연구원.

함형준, 김정원(2018). 초등학교 고학년 학생의 다문화수용성 제고를 위한 세계 전래동화 활용 교육 프로그램 개발. 다문화교육연구, 11(1), 109-132. 홍길희(2014). 일과를 통한 다문화교육 프로그램이 유아의 다문화 수용성과 친사회적 행동에 미치는 영향. 한국보육지원학회지, 10(6), 313-332.

\section{ORCID}

이은주(제1저자, 교신저자, 박사후연구원 https://orcid.org/ 0000-0003-2976-3151) 